Rakenteiden Mekaniikka (Journal of Structural Mechanics)

vol. 53, nro. 2, 2020, s. 145-179

http://rakenteidenmekaniikka.journal.fi/index

https://doi.org/10.23998/rm.85743

(C) 2019 kirjoittajat

Vapaasti saatavilla CC BY 4.0 -lisenssin mukaisesti

\title{
Tasorakenteiden ilmaääneneristävyyden arvioinnista
}

Jukka Aalto

Tiivistelmä Artikkelissa tarkastellaan rakenteiden ilmaääneneristävyyden laskennalliseen määrittämiseen liittyviä kysymyksiä rakennusinsinöörin näkökulmasta. Erityisesti tarkastellaan laattoja ja niistä koostuvia kerroksellisia tasorakenteita. Johdetaan esiteltyjen yhtälöiden analyyttisia ratkaisuja ja demonstroidaan niitä käyttäen ääneneristävyyden laskennallista määrittämistä.

Avainsanat: ilmaääni, tasoaalto, ääneneristävyys, äänenläpäisevyyskerroin, ääneneristysluku, laatta, aaltoimpedanssi

Vastaanotettu: 3.10.2019. Hyväksytty: 6.2.2020. Julkaistu verkossa: 30.3.2020.

emeritusprofessori Tapio Salmen muistolle

\section{Johdanto}

Tässä artikkelissa esitellään, kuinka rakenteiden âäneneristävyyttä voidaan arvioida laskennallisesti. Esitetyt yhtälöt ja analyyttiset ratkaisut eivät ole uusia, vaan ne löytyvät alan kirjallisuudesta, esimerkiksi lähteistä [1], [2], [3] ja [4]. Niiden johtamista ei kuitenkaan aina ole esitetty ja lähestymistapa voi olla rakennusinsinöörille vieras. Tässä artikkelissa esitettävät yhtälöt ja niiden ratkaisut on pyritty johtamaan mahdollisimman selkeästi ja johdonmukaisesti käyttäen rakenteiden mekaniikasta tuttuja käsitteitä. Tarkasteluissa käytetään sekä reaalisia että kompleksisia suureita. Esityksen selkeyttämiseksi nämä eritellään toisistaan käyttämällä reaalisille suureille kursivointia. Imaginaariyksikölle käytetään symbolia j. Vektoreille ja matriiseille käytetään tavanomaista lihavointia.

\section{Akustisen aaltoliikkeen yhtälöitä}

\section{Akustinen tasoaalto}

Akustiselle aaltoliikkeelle nesteessä on voimassa liikeyhtälö 
ja aaltoyhtälö

$$
\nabla p=-\rho \frac{\partial v}{\partial t}
$$

$$
\nabla^{2} p=\frac{1}{c^{2}} \frac{\partial^{2} p}{\partial t^{2}}
$$

missä $p(x, y, z, t)$ on akustinen paine, $v(x, y, z, t)$ partikkelinopeus, $\rho$ nesteen tiheys ja $c$ äänen nopeus nesteessä. Nimitystä neste (fluid) käytetään tässä sekä nesteelle (liquid) että kaasulle (gas). Tarkastellaan tasoaaltoa, joka etenee suuntaan, jonka määrittelee yksikkövektori

$$
\boldsymbol{e}=\cos \phi \sin \theta \boldsymbol{i}+\sin \phi \sin \theta \boldsymbol{j}+\cos \theta \boldsymbol{k}
$$

ja koordinaatti $s$ (kuva 1). Kulmia $\phi$ ja $\theta$ kutsutaan suuntakulmiksi.

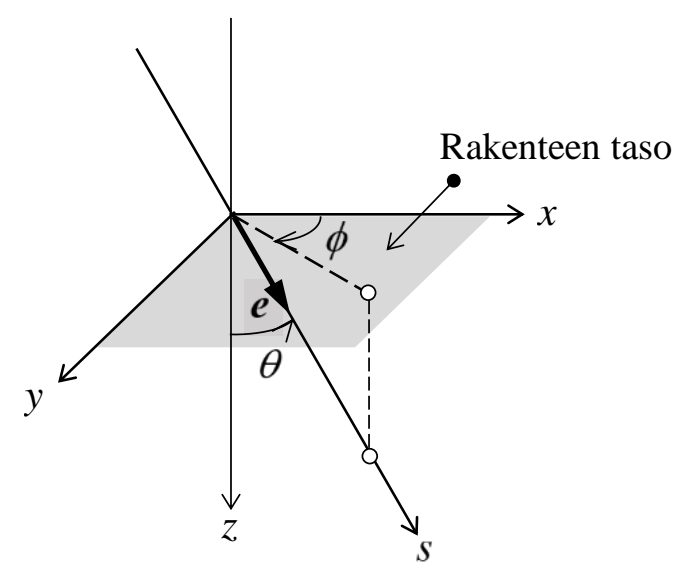

Kuva 1. Suuntakulmat $\phi$ ja $\theta$

Nyt $p=p(s, t)$ jav $(s, t)=v_{s}(s, t) \boldsymbol{e}$, jolloin liikeyhtälö (1) ja aaltoyhtälö (2) saavat muodot

$$
\frac{\partial v_{s}}{\partial t}=-\frac{1}{\rho} \frac{\partial p}{\partial s}
$$

ja

$$
\frac{\partial^{2} p}{\partial s^{2}}=\frac{1}{c^{2}} \frac{\partial^{2} p}{\partial t^{2}}
$$

Akustisissa tarkasteluissa osoittautuu tarkoituksenmukaiseksi käyttää fysikaalisten suureiden $p, \boldsymbol{v}$ ja $v_{s}$ sijasta kompleksisia suureita $\mathrm{p}, \mathbf{v}$ ja $\mathrm{v}_{s}$, koska niiden avulla monet tarkastelut yksinkertaistuvat huomattavasti. Helposti nähdään sijoittamalla, että kompleksinen paine

$$
\mathrm{p}(s, t)=\hat{\mathrm{p}} e^{\mathrm{j} \omega\left(t-\frac{s}{c}\right)},
$$

missä $\hat{\mathrm{p}}$ on kompleksinen amplitudi, toteuttaa aaltoyhtälön (5) ja on siis sen kompleksimuotoinen ratkaisu. On ilmeistä, että funktion (6) reaali- ja imaginaariosat erikseen toteuttavat yhtälön (5) ja ovat molemmat sen fysikaalisia ratkaisuja. Ottamalla amplitudille $\hat{\mathrm{p}}$ esitys

$$
\hat{\mathrm{p}}=\hat{p} e^{\mathrm{j} \varphi},
$$


missä

$$
\hat{p}=|\hat{\mathrm{p}}|, \quad \varphi=\arg (\hat{\mathrm{p}}),
$$

ovat reaalinen amplitudi ja vakio kulma, ja sijoittamalle se lausekkeeseen (6) saadaan kompleksinen paine muotoon

$$
\mathrm{p}(s, t)=\hat{p} e^{\mathrm{j}\left(\omega t-\omega \frac{s}{c}+\varphi\right)} .
$$

Ottamalla lausekkeen (10) reaaliosa, saadaan fysikaaliselle paineelle lauseke

$$
p(s, t) \equiv \operatorname{Re}[\mathrm{p}(s, t)]=\hat{p} \cos \left(\omega t-\omega \frac{s}{c}+\varphi\right) .
$$

Sijoituksella voidaan tarkistaa, että se toteuttaa aaltoyhtälön (5). Ottamalla vastaavasti lausekkeen (10) imaginaariosa, saataisiin fysikaaliselle paineelle sinimuotoinen lauseke, joka on myös aaltoyhtälön ratkaisu. Tässä työssä fysikaalisina suureina pidetään vastaavien kompleksisuureiden reaaliosia. Liikeyhtälöstä (4) seuraa

$$
\frac{\partial \mathrm{v}_{s}}{\partial t}=\frac{\mathrm{j} \omega}{\rho c} \hat{\mathrm{p}} e^{\mathrm{j} \omega\left(t-\frac{s}{c}\right)}
$$

Yhtälön (12) toteuttaa nopeus

$$
\mathrm{v}_{s}=\frac{\hat{\mathrm{p}}}{\rho c} e^{\mathrm{j} \omega\left(t-\frac{s}{c}\right)} .
$$

Kompleksinen nopeus $\mathrm{v}_{s}$ saadaan siis muotoon

$$
\mathrm{v}_{s}(s, t)=\hat{\mathrm{v}}_{s} e^{\mathrm{j} \omega\left(t-\frac{s}{c}\right)},
$$

missä sen kompleksinen amplitudi on

$$
\hat{\mathrm{v}}_{s}=\frac{\hat{\mathrm{p}}}{\rho c} .
$$

On siis huomattavaa, että tasoaallon nopeuden $s$-komponentin ja paineen kompleksisilla amplitudeilla on yhteys (15). Kompleksinen paine (6) voidaan esittää myös muodossa

missä

$$
\mathrm{p}(s, t)=\hat{\mathrm{p}} e^{\mathrm{j}(\omega t-k s)},
$$

$$
k=\frac{\omega}{c}
$$

on aaltoluku. Aaltoluvun ja aallonpituuden $\lambda$ välillä on yhteys $k=2 \pi / \lambda$, joten aaltoluku on kääntäen verrannollinen aallonpituuteen. Koordinaatille $s$ saadaan

$$
s=\boldsymbol{e} \cdot(x \boldsymbol{i}+y \boldsymbol{j}+z \boldsymbol{k})=x \cos \phi \sin \theta+y \sin \phi \sin \theta+z \cos \theta .
$$

Sijoittamalla tämä lausekkeeseen (16) saadaan suuntaan $\boldsymbol{e}$ etenevän tasoaallon kompleksiselle paineelle lauseke

$$
\mathrm{p}(x, y, z, t)=\hat{\mathrm{p}} e^{\mathrm{j}\left(\omega t-k_{x} x-k_{y} y-k_{z} z\right)},
$$

missä kertoimia

$$
k_{x}=k \cos \phi \sin \theta, \quad k_{y}=k \sin \phi \sin \theta, \quad k_{z}=k \cos \theta
$$

kutsutaan aaltoluvuiksi $x-, y$ - ja $z$-suunnissa. Niitä vastaavat aallonpituudet $x-, y$ - ja $z$-suunnissa ovat $\lambda_{x}=2 \pi / k_{x}, \lambda_{y}=2 \pi / k_{y}$ ja $\lambda_{z}=2 \pi / k_{z}$. 


\section{Laatta, jonka molemmin puolin on nestettä}

Tarkastellaan ääretöntä laattaa, jonka molemmilla puolilla on nestettä. Laatta on $(x, y)$ tason suuntainen ja $z$-akseli suuntautuu alaspäin. Laatta on siis vaakatasossa ja sen negatiivisen ja positiivisen $z$-akselin puoleisia avaruuden osia kutsutaan tässä ylä- ja alapuoliksi ja niihin viittaamaan käytetään alaindeksejä $-\mathrm{ja}+$. Laatan ylä- ja alapinnan $z$-koordinaatteja merkitään symboleilla $z_{-}$ja $z_{+}$. Jos laatan ylä- ja alapuolella on eri nestettä, käytetään niiden ominaisuuksille alaindeksejä - ja +. Koordinaatiston $(x, y, z)$ origoa ei aseteta tässä tarkastelussa laatan keskitasoon, kuten laattojen käsittelyssä tavallisesti tehdään.

\section{Laattaa kohtaava tasoaalto}

Tarkastellaan ääretöntä laattaa, jota kohtaa sen yläpuoleisesta puoliavaruudesta tasoaalto, jonka suuntakulmat ovat $\phi$ ja $\theta$. Tämän tuloaallon ( $I$, input wave) kompleksiselle paineelle otetaan esitys

$$
\mathrm{p}_{I}(x, y, z, t)=\hat{\mathrm{p}}_{I} e^{\mathrm{j}\left(\omega t-k_{x} x-k_{y} y-k_{z} z\right)},
$$

missä amplitudi $\hat{\mathrm{p}}_{I}$ on tunnettu kompleksinen vakio. Tasoaallon kohdatessa laatan, tuloaallon paine (21) ei sellaisenaan kuvaa tilannetta, vaan tarvitaan toinen, heijastunut aalto $(R$, reflected wave), jonka kompleksiselle paineelle otetaan esitys

$$
\mathrm{p}_{R}(x, y, z, t)=\hat{\mathrm{p}}_{R} e^{\mathrm{j}\left(\omega t-k_{x} x-k_{y} y-k_{R z} z\right)},
$$

jossa aaltoluvut $k_{x}$ ja $k_{y}$ ovat samat, mutta aaltoluku $k_{R z}$ poikkeaa tuloaallon aaltoluvusta $k_{z}$. Soveltamalla kaavoja (20a) ja (20b) tuloaallolle ja heijastuneelle aallolle saadaan yhtälöt

$$
\begin{aligned}
& k_{x}=k \cos \phi \sin \theta=k \cos \phi_{R} \sin \theta_{R}, \\
& k_{y}=k \sin \phi \sin \theta=k \sin \phi_{R} \sin \theta_{R},
\end{aligned}
$$

joista seuraa heijastuneen aallon suuntakulmille

$$
\begin{aligned}
& \phi_{R}=\phi, \\
& \left(\theta_{R}=\theta\right) \text { ja } \theta_{R}=\pi-\theta .
\end{aligned}
$$

Soveltamalla vielä kaavaa (20c) saadaan

$$
k_{z R}=k \cos \theta_{R}=-k \cos \theta=-k_{z} .
$$

Heijastuneen aallon kompleksisen paineen esitys on siis

$$
\mathrm{p}_{R}(x, y, z, t)=\hat{\mathrm{p}}_{R} e^{\mathrm{j}\left(\omega t-k_{x} x-k_{y} y+k_{z} z\right)} .
$$

Näin kokonaispaineelle laatan yläpuolella saadaan

$$
\mathrm{p}_{-}(x, y, z, t)=\mathrm{p}_{I}(x, y, z, t)+\mathrm{p}_{R}(x, y, z, t)=\left(\hat{\mathrm{p}}_{I} e^{-\mathrm{j} k_{z} z}+\hat{\mathrm{p}}_{R} e^{\mathrm{j} k_{z} z}\right) e^{\mathrm{j}\left(\omega t-k_{x} x-k_{y} y\right)} .
$$

Tässä kohdassa on tarkoituksenmukaista valita koordinaatiston origo laatan yläpinnalla, jolloin $z_{-}=0$. Paine (27) laatan yläpinnalla $z=0$ on siten

$$
\mathrm{p}_{-}(x, y, 0, t)=\left(\hat{\mathrm{p}}_{I}+\hat{\mathrm{p}}_{R}\right) e^{\mathrm{j}\left(\omega t-k_{x} x-k_{y} y\right)} .
$$

Se toimii laatalle kuormituksena, joten sen vaikutuksesta syntyvälle kompleksiselle taipumanopeudelle on luontevaa ottaa vastaava esitys

$$
\dot{\mathrm{w}}(x, y, t)=\hat{\dot{\mathrm{w}}} e^{\mathrm{j}\left(\omega t-k_{x} x-k_{y} y\right)},
$$


jonka aaltoluvut $k_{x}$ ja $k_{y}$ ovat samat. Tämä merkitsee sitä, että paineen ja taipumanopeuden aallonpituudet $x$ - ja $y$-suunnissa $\lambda_{x}$ ja $\lambda_{y}$ ovat samat ja aallot siis yhtyvät. Laatan yläpinnalla $z=0$ on voimassa reunaehto, joka saadaan soveltamalla kolmatta liikeyhtälöä (1) laatan pinnalla ja ottamalla huomioon, että $v_{z}(x, y, 0, t)=\dot{w}(x, y, t)$, missä $\dot{w}$ on laatan taipumanopeus. Saadaan yhtälö

$$
\frac{\partial \mathrm{p}_{-}}{\partial z}(x, y, 0, t)=-\rho_{-} \frac{\partial \dot{\mathrm{w}}}{\partial t}(x, y, t),
$$

missä $\rho_{-}$on laatan yläpuoleisen nesteen tiheys ja $\dot{\mathrm{w}}(x, y, t)$ on laatan kompleksinen taipumanopeus. Sijoittamalla lausekkeet (27) ja (29) reunaehtoyhtälöön (30) saadaan

$$
\mathrm{j} k_{z}\left(-\hat{\mathrm{p}}_{I}+\hat{\mathrm{p}}_{R}\right) e^{\mathrm{j}\left(\omega t-k_{x} x-k_{y} y\right)}=-\mathrm{j} \omega \rho_{-} \hat{\dot{\mathrm{w}}} e^{\mathrm{j}\left(\omega t-k_{x} x-k_{y} y\right)}
$$

ja soveltamalla laatan yläpuolella yhteyttä (20c) paine- ja taipuma-amplitudeille yhteys

$$
\hat{\mathrm{p}}_{R}=\hat{\mathrm{p}}_{I}-\frac{\rho_{-} c_{-}}{\cos \theta} \hat{\mathrm{W}} \text {. }
$$

\section{Laatan synnyttämä tasoaalto}

Tarkastellaan harmonisesti värähtelevää ääretöntä laatta, jonka taipumanopeus on muotoa (29). Sen alapuoleiseen puoliavaruuteen syntyvän aallon kompleksiselle paineelle otetaan vastaavin perustein kuin kohdassa 2.3 esitys

$$
\mathrm{p}_{+}(x, y, z, t)=\hat{\mathrm{p}}_{+} e^{\mathrm{j}\left(\omega t-k_{x} x-k_{y} y-k_{z} z\right)} .
$$

Reunaehtoyhtälö laatan alapinnalla $z=z_{+}$on

$$
\frac{\partial \mathrm{p}_{+}}{\partial z}\left(x, y, z_{+}, t\right)=-\rho_{+} \frac{\partial \dot{\mathrm{w}}}{\partial t}(x, y, t),
$$

missä $\rho_{+}$on laatan alapuoleisen ( $z$-akselin positiivisen suunnan puoleisen) nesteen tiheys. Sijoittamalla tähän lausekkeet (29) ja (33) saadaan yhtälö

$$
-\mathrm{j} k_{z} \hat{\mathrm{p}}_{+} e^{-\mathrm{j} k_{z} z_{+}} e^{\mathrm{j}\left(\omega t-k_{x} x-k_{y} y\right)}=-\mathrm{j} \omega \rho_{+} \hat{\dot{\mathrm{w}}} e^{\mathrm{j}\left(\omega t-k_{x} x-k_{y} y\right)},
$$

josta seuraa soveltamalla vielä laatan alapuolella yhteyttä (20c) laatan synnyttämän aallon kompleksisen paineen amplitudille tulos

$$
\hat{\mathrm{p}}_{+}=e^{\mathrm{j} k_{z} z_{+}} \frac{\rho_{+} c_{+}}{\cos \theta_{+}} \hat{\dot{\mathrm{w}}}
$$

\section{Kahden laatan välinen tasoaalto}

Tarkastellaan kahta laattaa 1 ja 2 sekä niiden välissä olevaa nestettä. Laattojen taipumanopeuksille otetaan esitykset

$$
\dot{\mathrm{w}}_{1}(x, y, t)=\hat{\dot{\mathrm{w}}}_{1} e^{\mathrm{j}\left(\omega t-k_{x} x-k_{y} y\right)}, \quad \dot{\mathrm{w}}_{2}(x, y, t)=\hat{\dot{\mathrm{w}}}_{2} e^{\mathrm{j}\left(\omega t-k_{x} x-k_{y} y\right)} .
$$

Laattojen väliseen nesteeseen syntyy $z$-akselin positiiviseen ja negatiiviseen suuntaan etenevät aallot $A$ ja $B$, joiden paineille otetaan esitykset

$$
\mathrm{p}_{A}(x, y, z, t)=\hat{\mathrm{p}}_{A} e^{\mathrm{j}\left(\omega t-k_{x} x-k_{y} y-k_{z} z\right)}, \quad \mathrm{p}_{B}(x, y, z, t)=\hat{\mathrm{p}}_{B} e^{\mathrm{j}\left(\omega t-k_{x} x-k_{y} y+k_{z} z\right)}
$$

ja kokonaispaine on

$$
\mathrm{p}=\mathrm{p}_{A}+\mathrm{p}_{B}=\left(\hat{\mathrm{p}}_{A} e^{-\mathrm{j} k_{z} z}+\hat{\mathrm{p}}_{B} e^{\mathrm{j} k_{z} z}\right) e^{\mathrm{j}\left(\omega t-k_{x} x-k_{y} y\right)}
$$


Reunaehdot laattojen nesteeseen rajoittuvilla pinnoilla $z=z_{1+}$ ja $z=z_{2-}$ ovat

$$
\frac{\partial \mathrm{p}}{\partial z}\left(x, y, z_{1+}, t\right)=-\rho \frac{\partial \dot{\mathrm{w}}_{1}}{\partial t}(x, y, t), \frac{\partial \mathrm{p}}{\partial z}\left(x, y, z_{2-}, t\right)=-\rho \frac{\partial \dot{\mathrm{w}}_{2}}{\partial t}(x, y, t) .
$$

Niistä seuraa

$$
\begin{aligned}
& -\mathrm{j} k_{z}\left(\hat{\mathrm{p}}_{A} e^{-\mathrm{j} k_{z} z_{1+}}-\hat{\mathrm{p}}_{B} e^{\mathrm{j} k_{z} z_{1+}}\right)=-\rho \mathrm{j} \omega \hat{\dot{\mathrm{w}}}_{1}, \\
& -\mathrm{j} k_{z}\left(\hat{\mathrm{p}}_{A} e^{-\mathrm{j} k_{z} z_{2-}}-\hat{\mathrm{p}}_{B} e^{\mathrm{j} k_{z} z_{2-}}\right)=-\rho \mathrm{j} \omega \hat{\dot{\mathrm{w}}}_{2}
\end{aligned}
$$

ja edelleen yhtälöt

$$
\begin{aligned}
& e^{-\mathrm{j} k_{z} z_{1}} \hat{\mathrm{p}}_{A}-e^{\mathrm{j} k_{z} z_{1}} \hat{\mathrm{p}}_{B}=\frac{\rho c}{\cos \theta} \hat{\mathrm{\textrm {w }}}_{1} \\
& e^{-\mathrm{j} k_{z} z_{2}-} \hat{\mathrm{p}}_{A}-e^{\mathrm{j} k_{z} z_{2}-} \hat{\mathrm{p}}_{B}=\frac{\rho c}{\cos \theta} \hat{\mathrm{w}}_{2} .
\end{aligned}
$$

Ratkaisemalla näistä yhtälöistä paineamplitudit, saadaan

$$
\begin{aligned}
& \hat{\mathrm{p}}_{A}=\frac{\mathrm{j}}{2 \sin k_{z} d} \frac{\rho c}{\cos \theta}\left(-e^{\mathrm{j} k_{z} z_{2-}} \hat{\dot{\mathrm{w}}}_{1}+e^{\mathrm{j} k_{z} z_{1+}} \hat{\dot{\mathrm{w}}}_{2}\right), \\
& \hat{\mathrm{p}}_{B}=\frac{\mathrm{j}}{2 \sin k_{z} d} \frac{\rho c}{\cos \theta}\left(-e^{-\mathrm{j} k_{z} z_{2-}} \hat{\dot{\mathrm{w}}}_{1}+e^{-\mathrm{j} k_{z} z_{1+}} \hat{\dot{\mathrm{w}}}_{2}\right),
\end{aligned}
$$

missä $d=z_{2-}-z_{1+}$ on laattojen välisen nestekerroksen paksuus.

\section{Ääneneristävyys}

\section{Akustinen intensiteetti ja äänen teho}

Aluksi tarkastellaan, kuinka rakenteen ääneneristävyys voidaan määrittää, kun siihen kohdistuu tasoaalto, jonka taajuus on $f$ ja suuntakulmat $\phi$ ja $\theta$. Tarkastelussa hyödyllinen käsite on akustinen intensiteetti $I$, jota tarkastellaan tässä lähteen [3] hengessä. Se määritellään suureena, jonka avulla äänen tehon aikakeskiarvo pinnalla $A$ saadaan kaavalla

$$
<P>=\int_{A} I d A
$$

Äänen teho pinnalla $A$ on

$$
P=\int_{A} p v_{n} d A
$$

missä $p$ on fysikaalinen paine ja $v_{n}$ on nopeuden normaalikomponentti. Sen aikakeskiarvolle saadaan

$$
<P>=\frac{1}{T} \int_{0}^{T} P d t=\int_{A} \frac{1}{T} \int_{0}^{T} p v_{n} d t d A,
$$

missä $T=1 / f=2 \pi / \omega$ on jaksonaika. Kaavoista (44) ja (46) seuraa akustiselle intensiteetille lauseke

$$
I=\frac{1}{T} \int_{0}^{T} p v_{n} d t
$$


Jos kysymyksessä on tasoaalto, jonka suunnan määrittelee yksikkövektori $\boldsymbol{e}$ ja joka kohtaa $(x, y)$-tason suuntaisen tasopinnan, se saadaan muotoon

$$
I=\frac{1}{T} \int_{0}^{T} p v_{z} d t=\frac{1}{T} \int_{0}^{T} p v_{s} d t \cos \theta
$$

Fysikaaliselle paineelle ja $s$-nopeudelle saadaan

$$
\begin{aligned}
& p=\operatorname{Re}(\mathrm{p})=\hat{p} \cos \left(\omega t-\frac{\omega}{c} s+\varphi\right), \\
& v_{s}=\operatorname{Re}\left(\mathrm{v}_{s}\right)=\hat{v}_{s} \cos \left(\omega t-\frac{\omega}{c} s+\varphi\right)=\frac{\hat{p}}{\rho c} \cos \left(\omega t-\frac{\omega}{c} s+\varphi\right) .
\end{aligned}
$$

Näin akustiselle intensiteetille saadaan

$$
I=\frac{1}{T} \frac{\hat{p}^{2}}{\rho c} \int_{0}^{T} \cos ^{2}\left(\omega t-\frac{\omega}{c} s+\varphi\right) d t \cos \theta=\frac{\hat{p}^{2}}{2 \rho c} \cos \theta,
$$

joka on vakio. Pinnan $A$ läpi virtaavan äänen tehon aikakeskiarvolle saadaan tässä tapauksessa

$$
<P>=I A
$$

\section{Rakenteen äänenläpäisevyyskerroin ja ääneneristävyys}

Rakenteen äänenläpäisevyyskerroin vinosti kohtaavalle ääniaallolle määritellään kaavalla

$$
\tau_{<}=\frac{<P_{T}>}{<P_{I}>} .
$$

Sille käytetään alaindeksiä $\angle$ tähdentämään kohtaamisen vinoutta $(\theta \geq 0)$. Jatkossa osoittautuu, että yleisessä tapauksessa $\tau_{\llcorner}$riippuu molemmista suuntakulmista $\phi$ ja $\theta$. Läpäisseen- ja tuloaallon tehojen aikakaskiarvot ovat

$$
<P_{T}>=I_{T} A, \quad<P_{I}>=I_{I} A,
$$

missä $A$ on rakenteen ääntä läpäisevä pinta, ja niiden akustiset intensiteetit ovat

$$
I_{T}=\frac{\hat{p}_{T}{ }^{2}}{2 \rho_{+} c_{+}} \cos \theta_{+}, \quad I_{I}=\frac{\hat{p}_{I}{ }^{2}}{2 \rho_{-} c_{-}} \cos \theta_{-},
$$

missä alaindeksit - ja + viittaavat rakenteen ylä- ja alapuoleen. Rakenteen äänenläpäisevyyskertoimelle saadaan nyt

$$
\tau_{\llcorner}=\frac{I_{T}}{I_{I}}=\frac{\rho_{-} c_{-}}{\rho_{+} c_{+}} \frac{\cos \theta_{+}}{\cos \theta_{-}} \frac{\hat{p}_{T}^{2}}{\hat{p}_{I}^{2}} \equiv \frac{\rho_{-} c_{-}}{\rho_{+} c_{+}} \frac{\cos \theta_{+}}{\cos \theta_{-}}\left|\frac{\hat{\mathrm{p}}_{T}}{\hat{\mathrm{p}}_{I}}\right|^{2} .
$$

Jotta kaavaa (55) voidaan käyttää, täytyy läpäisseen aallon suuntakulma $\theta_{+}$tuntea. Koska aaltoluvut $k_{x}$ ja $k_{y}$ rakenteen ylä- ja alapuoleisessa nesteessä ovat samat, saadaan kaavojen (20a) ja (20b) perusteella yhtälöt

$$
\begin{aligned}
& k_{-} \cos \phi_{-} \sin \theta_{-}=k_{+} \cos \phi_{+} \sin \theta_{+}, \\
& k_{-} \sin \phi_{-} \sin \theta_{-}=k_{+} \sin \phi_{+} \sin \theta_{+},
\end{aligned}
$$

joista seuraa $\phi_{+}=\phi_{-}$ja 


$$
\theta_{+}=\arcsin \left(\frac{k_{-}}{k_{+}} \sin \theta_{-}\right)=\arcsin \left(\frac{c_{+}}{c_{-}} \sin \theta_{-}\right) .
$$

Tavallisesti rakenteen molemmin puolin on sama neste (ilma), jolloin kaava (55) yksinkertaistuu muotoon

$$
\tau_{\angle}=\left|\frac{\hat{\mathrm{p}}_{T}}{\hat{\mathrm{p}}_{I}}\right|^{2} .
$$

Rakenteen ääneneristävyys $[\mathrm{dB}]$ vinosti kohtaavalle ääniaallolle määritellään äänen-läpäisevyyskertoimen avulla kaavalla

$$
R_{\llcorner}=10 \lg \frac{1}{\tau_{\llcorner}} .
$$

\section{Rakenteen ääneneristävyys diffuusille kentälle}

Todellisuudessa ääni ei koskaan kohtaa rakennetta vain yhdestä suunnasta. Siksi rakenteen äänenläpäisevyyttä tutkittaessa otaksutaan, että siihen kohdistuu diffuusi kenttä, jossa eri suunnista rakenteeseen kohdistuvilla tasoaalloilla on sama todennäköisyys. Tarkasteluun ei kuitenkaan sisällytetä aaltoja, joiden suuntakulma $\theta$ ylittää tietyn kokemusperäisen rajakulman $\bar{\theta}$, jolle käytetään [4] arvoa $78^{\circ}$. Rakenteen pinnan loivasti kohtaavat aallot näet heijastuvat eivätkä läpäise rakennetta. Rakenteen äänenläpäisevyyskerroin diffuusille kentälle määritellään kaavalla

$$
\tau=\frac{\int_{S} I_{T}(\phi, \theta) d S}{\int_{S} I_{I}(\theta) d S}
$$

missä integrointi tapahtuu tarkasteltavaa pistettä ympäröivän $r_{0}$-säteisen pallokalotin $S$ yli, jonka keskuskulma on $\bar{\theta}$. Pinta-alkiolle saadaan

$$
d S=r_{0} \sin \theta d \phi \cdot r_{0} d \theta=r_{0}^{2} \sin \theta d \phi d \theta .
$$

Nyt saadaan

$$
\begin{aligned}
& \int_{S} I_{I} d S=\int_{S} \frac{\hat{p}_{I}^{2}}{\rho_{-} c_{-}} \cos \theta d S=\frac{\hat{p}_{I}^{2}}{\rho_{-} c_{-}} r_{0}^{2} \int_{0}^{2 \pi} \int_{0}^{\bar{\theta}} \cos \theta \sin \theta d \phi d \theta, \\
& \int_{S} I_{T} d S=\int_{S} \tau_{L}(\phi, \theta) I_{I} d S=\frac{\hat{p}_{I}^{2}}{\rho_{+} c_{+}} r_{0}^{2} \int_{0}^{2 \pi} \int_{0}^{\bar{\theta}} \tau_{L}(\phi, \theta) \cos \theta \sin \theta d \phi d \theta,
\end{aligned}
$$

jolloin äänenläpäisevyyskertoimelle $\tau$ saadaan tulos

$$
\tau=\frac{\int_{0}^{2 \pi} \int_{0}^{\bar{\theta}} \tau_{L}(\phi, \theta) \cos \theta \sin \theta d \phi d \theta}{\int_{0}^{2 \pi} \int_{0}^{\bar{\theta}} \cos \theta \sin \theta d \phi d \theta}=\frac{1}{\pi \sin ^{2} \bar{\theta}} \int_{0}^{2 \pi}\left[\int_{0}^{\bar{\theta}} \tau_{L}(\phi, \theta) \sin \theta \cos \theta d \theta\right] d \phi .
$$

Symmetrian vuoksi voidaan se vielä kirjoittaa muotoon

$$
\tau=\frac{2}{\pi \sin ^{2} \bar{\theta}} \int_{0}^{\pi}\left[\int_{0}^{\bar{\theta}} \tau_{\llcorner}(\phi, \theta) \sin \theta \cos \theta d \theta\right] d \phi .
$$


Äänenläpäisevyyskertoimen lauseke $\tau_{\angle}(\phi, \theta)$ on yleensä niin monimutkainen, että kaavan (64) integroinnit muuttujien $\phi$ ja $\theta$ yli joudutaan suorittamaan numeerisesti soveltamalla puolisuunnikassääntöä. Monissa tärkeissä käytännön tapauksissa tasoaallon äänenläpäisevyyskerroin riippuu vain suuntakulmasta $\theta$. Tällöin äänenläpäisevyyskertoimen $\tau$ lauseke (64) yksinkertaistuu muotoon

$$
\tau=\frac{2}{\sin ^{2} \bar{\theta}} \int_{0}^{\bar{\theta}} \tau_{L}(\theta) \sin \theta \cos \theta d \theta .
$$

Tässä tapauksessa numeerinen integrointi tapahtuu vain muuttujan $\theta$ yli.

Rakenteen ääneneristävyys $R[\mathrm{~dB}]$ diffuusille kentälle saadaan äänenläpäisevyyskertoimen avulla $\tau$ kaavalla

$$
R=10 \lg \frac{1}{\tau}
$$

Se riippuu taajuudesta ja esitetään usein graafisesti taajuuden logaritmin funktiona.

Huomautus: Lähteessä [1], [3], ja [4] on esitetty äänenläpäisevyyskertoimen $\tau$ kaava (65) ja lähteessä [3] sen johto. Niissä on siis rajoituttu tapaukseen, jossa $\tau_{\angle}$ riippuu vain suuntakulmasta $\theta$. Yleisessä tapauksessa on käytettävä kaavaa (64).

\section{Laskennallinen ääneneristävyyskäyrä}

Kokeellisesti ääneneristävyys mitataan [5] 1/3-oktaavin levyisillä kohinaäänikaistoilla kuudellatoista eri taajuudella välillä $100 \ldots 3150$ Hz. Mittaustulos esitetään käyränä (murtoviivana) koordinaatistossa, jonka abskissa on taajuuden logaritmi ja ordinaatta ääneneristävyys. Määritettäessä ääneneristävyyttä laskennallisesti voidaan konstruoida vastaavanlainen käyrä. Tarkasteltava taajuusalue jaetaan kuuteentoista 1/3-oktaavikaistaan $i=1, \cdots, 16$, joiden ala- ja ylärajat $f_{i}^{\text {ala }}$ ja $f_{i}^{\text {ylä }}$ sekä keskipisteet $\bar{f}_{i}$ on esitetty taulukossa 1. Ääneneristävyyden keskimääräinen suuruus kaistassa $i$ määritellään lausekkeena

$$
\bar{R}_{i}=\frac{1}{f_{i}^{y l a ̈}-f_{i}^{a l a}} \int_{f_{i}^{a l a}}^{f_{i}^{y l a}} R(f) d f,
$$

missä $R(f)$ on ääneneristävyys taajuuden $f$ funktiona. Integrointi kaavassa (67) suoritetaan numeerisesti käyttäen puolisuunnikassääntöä. Kun kaistojen keskimääräiset ääneneristävyydet $\bar{R}_{i}$ on määritetty, esitetään tulos murtoviivana, jonka kulmapisteiden $i$ koordinaatit ovat $x_{i}=\lg \bar{f}_{i}$ ja $y_{i}=\bar{R}_{i}$. Sitä kutsutaan tässä laskennalliseksi ääneneristävyyskäyräksi.

\section{Ilmaääneneristysluku}

Usein rakenteen ilmaääneneristävyys halutaan esittää yhdellä luvulla. Tällainen on ilmaääneneristysluku $R_{w}$ [dB], joka määritetään seuraavasti [5]. Ääneneristävyyskäyrän koordinaatistoon asetetaan kolmesta suorasta osasta muodostuva vertailukäyrä (murtoviiva), jonka ordinaattaa kahdeksannen oktaavikaistan keskuksen $\bar{f}_{8}=500 \mathrm{~Hz}$ kohdalla merkitään symbolilla $y_{8}$ ja jonka arvot $y_{i}^{\text {vert }}$ kaistojen keskusten $\bar{f}_{i}$ kohdilla on esitetty $\left(y_{8}: \mathrm{n}\right.$ avulla) taulukossa 1 . Valitaan aluksi $y_{8}:$ n arvoksi suurin kokonaisluku, jolla ääneneris- 
tävyyskäyrän kulmapisteiden poikkeamien summa vertailukäyrän alapuolella on enintään $32 \mathrm{~dB}$. Jos samanaikaisesti pisteiden suurin poikkeama vertailukäyrästä on enintään $8 \mathrm{~dB}$, ilmaääneneristysluku on $R_{w}=y_{8}$. Jos suurin poikkeama ylittää $8 \mathrm{~dB}$, valitaan $y_{8}$ :n uudeksi arvoksi suurin kokonaisluku, jolla samanaikaisesti ilmaääneneristävyyskäyrän kulmapisteiden poikkeamien summa vertailukäyrän alapuolella on enintään $24 \mathrm{~dB}$ ja suurin poikkeama enintään $12 \mathrm{~dB}$. Tällöin ilmaääneneristysluku on $R_{w}=y_{8}$.

Taulukko 1. 1/3-oktaavikaistojen ala- ja ylärajat, keskipisteet sekä vertailukäyrän ordinaatat [5].

\begin{tabular}{lllll}
\hline$i$ & $f_{i}^{\text {ala }}$ & $f_{i}^{\text {ylä }}$ & $\bar{f}_{i}$ & $y_{i}^{\text {vert }}$ \\
\hline 1 & 89.1 & 112 & 100 & $y_{8}-19$ \\
2 & 112 & 141 & 125 & $y_{8}-16$ \\
3 & 141 & 178 & 160 & $y_{8}-13$ \\
4 & 178 & 224 & 200 & $y_{8}-10$ \\
5 & 224 & 282 & 250 & $y_{8}-7$ \\
6 & 282 & 355 & 315 & $y_{8}-4$ \\
7 & 355 & 447 & 400 & $y_{8}-1$ \\
8 & 447 & 562 & 500 & $y_{8}$ \\
9 & 562 & 708 & 630 & $y_{8}+1$ \\
10 & 708 & 891 & 800 & $y_{8}+2$ \\
11 & 891 & 1122 & 1000 & $y_{8}+3$ \\
12 & 1122 & 1413 & 1250 & $y_{8}+4$ \\
13 & 1413 & 1778 & 1600 & $y_{8}+4$ \\
14 & 1778 & 2239 & 2000 & $y_{8}+4$ \\
15 & 2239 & 2818 & 2500 & $y_{8}+4$ \\
16 & 2818 & 3548 & 3150 & $y_{8}+4$ \\
\hline
\end{tabular}

\section{Laatan aaltoimpedanssi}

\section{Laatan aaltoimpedanssin määrittely}

Hyödyllinen käsite, jota voidaan käyttää laatan ja laatoista koostuvan tasorakenteen ääneneristävyyden määrittämisen yhteydessä on laatan aaltoimpedanssi (wave impedance) [2], jolle käytetään myös nimitystä separaatioimpedanssi (separation impedance) [1]. Esitetään laattaan kohdistuva harmoninen kompleksimuotoinen jakautunut kuormitus, sen synnyttämä taipuma ja taipumanopeus muodoissa

$$
\begin{aligned}
\mathrm{q}(x, y, t) & =\hat{\mathrm{q}} e^{\mathrm{j}\left(\omega t-k_{x} x-k_{y} y\right)}, \\
\mathrm{w}(x, y, t) & =\hat{\mathrm{w}} e^{\mathrm{j}\left(\omega t-k_{x} x-k_{y} y\right)}
\end{aligned}
$$

ja

$$
\dot{\mathrm{W}}(x, y, t)=\hat{\dot{\mathrm{w}}} e^{\mathrm{j}\left(\omega t-k_{x} x-k_{y} y\right)} .
$$


Kompleksiselle taipumanopeudelle saadaan

$$
\dot{\mathrm{w}}(x, y, t) \equiv \frac{\partial \mathrm{w}}{\partial t}=\mathrm{j} \omega \hat{\mathrm{w}} e^{\mathrm{j}\left(\omega t-k_{x} x-k_{y} y\right)},
$$

joten sen ja taipuman kompleksilla amplitudeilla on yhteys

$$
\hat{\dot{\mathrm{w}}}=\mathrm{j} \omega \hat{\mathrm{w}} \text {. }
$$

Laatan aaltoimpedanssi määritellään nyt laatan kuormituksen ja sen aiheuttaman taipumanopeuden kompleksisten amplitudien suhteena

$$
\mathrm{Z}^{*}=\frac{\hat{\mathrm{q}}}{\hat{\dot{\mathrm{w}}}} \text {. }
$$

Kun laatan aaltoimpedanssi tunnetaan, voidaan laattaan kohdistuvan kuorman ja siitä aiheutuvan taipumanopeuden kompleksisten amplitudien välinen yhteys esittää muodossa

$$
\mathrm{Z}^{*} \hat{\mathrm{w}}=\hat{\mathrm{q}} \text {. }
$$

Seuraavassa johdetaan aaltoimpedanssin lauseke ortotrooppiselle Kirchhoff-laatalle ja isptrooppiselle Reissner-Mindlin-laatalle.

\section{Kirchhoff-laatan aaltoimpedanssi}

Ortotrooppisen Kirchhoff-laatan taipuman $w(x, y, t)$ differentiaaliyhtälö [7] on muotoa

$$
B_{x} \frac{\partial^{4} w}{\partial x^{4}}+2 H \frac{\partial^{4} w}{\partial x^{2} \partial y^{2}}+B_{y} \frac{\partial^{4} w}{\partial y^{4}}+m \frac{\partial^{2} w}{\partial t^{2}}-q=0
$$

missä $q(x, y, t)$ on laattaan kohdistuva jakautunut kuormitus ja $m$ laatan pintamassa. Kerroin $H=B_{1}+2 B_{x y}$ ja sekä $B_{x}, B_{y}, B_{1}$ ja $B_{x y}$ ovat laatan taivutusjäykkyydet. Kompleksisen taipuman $\mathrm{w}(x, y, t)$ ja kuormituksen $\mathrm{q}(x, y, t)$ tapauksessa yhtälö (75) esitetään muodossa

$$
\mathrm{B}_{x} \frac{\partial^{4} \mathrm{w}}{\partial x^{4}}+2 \mathrm{H} \frac{\partial^{4} \mathrm{w}}{\partial x^{2} \partial y^{2}}+\mathrm{B}_{y} \frac{\partial^{4} \mathrm{w}}{\partial y^{4}}+m \frac{\partial^{2} \mathrm{w}}{\partial t^{2}}-\mathrm{q}=0 .
$$

Tarkasteluun on samalla sisällytetty kompleksijäykkyysvaimennus, ottamalla käyttöön kompleksiset taivutusjäykkyydet

$$
\mathrm{B}_{x}=B_{x}(1+\mathrm{j} \eta), \quad \mathrm{H}=H(1+\mathrm{j} \eta), \quad \mathrm{B}_{y}=B_{y}(1+\mathrm{j} \eta),
$$

missä $\eta$ on häviöluku. Sijoittamalla taipuman ja kuorman lausekkeet (68) ja (69) yhtälöön (76) saadaan amplitudien $\hat{\mathrm{w}}$ ja $\hat{\mathrm{q}}$ välille yhtälö

$$
\left(\mathrm{B}_{x} k_{x}^{4}+2 \mathrm{H} k_{x}^{2} k_{y}^{2}+\mathrm{B}_{y} k_{y}^{4}-m \omega^{2}\right) \hat{\mathrm{w}}=\hat{\mathrm{q}} .
$$

Soveltamalla vielä yhteyttä (72) saadaan amplitudien $\hat{\dot{W}}$ ja $\hat{q}$ välille yhteys

$$
\mathrm{j}\left(m \omega-\frac{\mathrm{B}_{x} k_{x}^{4}+2 \mathrm{H} k_{x}^{2} k_{y}^{2}+\mathrm{B}_{y} k_{y}^{4}}{\omega}\right) \hat{\dot{\mathrm{w}}}=\hat{\mathrm{q}} .
$$

Vertaamalla yhtälöitä (74) ja (79) saadaan ortotrooppisen Kirchhoff-laatan aaltoimpedanssille tulos

$$
\mathrm{Z}^{*}=\mathrm{j}\left(m \omega-\frac{\mathrm{B}_{x} k_{x}^{4}+2 \mathrm{H} k_{x}^{2} k_{y}^{2}+\mathrm{B}_{y} k_{y}^{4}}{\omega}\right)
$$

Jos kysymyksessä on isotrooppinen laatta, 


$$
B_{x}=B_{y}=H=B \equiv \frac{E h^{3}}{12\left(1-v^{2}\right)}
$$

ja sen aaltoimpedanssille saadaan

missä

$$
\mathrm{Z}^{*}=\mathrm{j}\left[m \omega-\frac{\mathrm{B}}{\omega}\left(\frac{\omega}{c}\right)^{4} \sin ^{4} \theta\right],
$$

$$
\mathrm{B}=B(1+\mathrm{j} \eta)
$$

\section{Reissner-Mindlin-laatan aaltoimpedanssi}

Tarkastellaan tässä isotrooppista Reissner-Mindlin-laattaa, johon on sisällytetty rotaatiohitauden vaikutus. Sen taipuman differentiaaliyhtälö on johdettu liitteessä A (kaava (A.16)) ja on muotoa

$$
B \nabla^{4} w-\left(J+\frac{m B}{S}\right) \nabla^{2} \frac{\partial^{2} w}{\partial t^{2}}+\frac{m J}{S} \frac{\partial^{4} w}{\partial t^{4}}+m \frac{\partial^{2} w}{\partial t^{2}}=q-\frac{B}{S} \nabla^{2} q+\frac{J}{S} \frac{\partial^{2} q}{\partial t^{2}},
$$

missä $B$ ja $S$ ovat sen taivutus- ja leikkausjäykkyydet sekä $J$ on rotaatiohitaus. Vastaava kompleksimuotoinen yhtälö on

$$
\mathrm{B} \nabla^{4} \mathrm{w}-\left(J+\frac{m \mathrm{~B}}{\mathrm{~S}}\right) \nabla^{2} \frac{\partial^{2} \mathrm{w}}{\partial t^{2}}+\frac{m J}{\mathrm{~S}} \frac{\partial^{4} \mathrm{w}}{\partial t^{4}}+m \frac{\partial^{2} \mathrm{w}}{\partial t^{2}}=\mathrm{q}-\frac{\mathrm{B}}{\mathrm{S}} \nabla^{2} \mathrm{q}+\frac{J}{\mathrm{~S}} \frac{\partial^{2} \mathrm{q}}{\partial t^{2}},
$$

missä kompleksiset jäykkyydet ovat

$$
\mathrm{B}=B(1+\mathrm{j} \eta), \quad \mathrm{S}=S(1+\mathrm{j} \eta) .
$$

Sijoittamalla taipuman ja kuorman lausekkeet (68) ja (69) yhtälöön (85) saadaan yhtälö

$$
\begin{aligned}
& {\left[\mathrm{B} \frac{\omega^{4}}{c^{4}} \sin ^{4} \theta-\left(J+\frac{m \mathrm{~B}}{\mathrm{~S}}\right) \frac{\omega^{4}}{c^{2}} \sin ^{2} \theta+\frac{m J}{\mathrm{~S}} \omega^{4}-m \omega^{2}\right] \hat{\mathrm{w}}} \\
& =\left(1+\frac{\mathrm{B}}{\mathrm{S}} \frac{\omega^{2}}{c^{2}} \sin ^{2} \theta-\frac{J}{\mathrm{~S}} \omega^{2}\right) \hat{\mathrm{q}},
\end{aligned}
$$

Soveltamalla vielä yhteyttä (72) saadaan amplitudien $\hat{\dot{\mathrm{W}}}$ ja $\hat{\mathrm{q}}$ välille yhteys

$$
\mathrm{j} \omega \frac{m-\mathrm{B} \frac{\omega^{2}}{c^{4}} \sin ^{4} \theta+\left(J+\frac{m \mathrm{~B}}{\mathrm{~S}}\right) \frac{\omega^{2}}{c^{2}} \sin ^{2} \theta-\frac{m J}{\mathrm{~S}} \omega^{2}}{1+\frac{\mathrm{B}}{\mathrm{S}} \frac{\omega^{2}}{c^{2}} \sin ^{2} \theta-\frac{J}{\mathrm{~S}} \omega^{2}} \hat{\mathrm{w}}=\hat{\mathrm{q}} .
$$

Vertaamalla yhtälöitä (74) ja (88) saadaan isotrooppisen Reissner-Mindlin-laatan aaltoimpedanssille tulos

Jos laatta on homogeeninen

$$
\mathrm{Z}^{*}=\mathrm{j} \omega \frac{m-\mathrm{B} \frac{\omega^{2}}{c^{4}} \sin ^{4} \theta+\left(J+\frac{m \mathrm{~B}}{\mathrm{~S}}\right) \frac{\omega^{2}}{c^{2}} \sin ^{2} \theta-\frac{m J}{\mathrm{~S}} \omega^{2}}{1+\frac{\mathrm{B}}{\mathrm{S}} \frac{\omega^{2}}{c^{2}} \sin ^{2} \theta-\frac{J}{\mathrm{~S}} \omega^{2}} .
$$

$$
B=\frac{E h^{3}}{12\left(1-v^{2}\right)}, S=k G h, J=\frac{m h^{2}}{12},
$$


missä $k=5$ / 6 on leikkauskorjauskerroin. Jos lisäksi vaimennus jätetään huomiotta, jolloin $\mathrm{B}=B$ ja $\mathrm{S}=S$, aaltoimpedanssin lauseke (89) saa muodon

$$
\mathrm{Z}^{*}=\mathrm{j} \omega \frac{m-B \frac{\omega^{2}}{c^{4}} \sin ^{4} \theta+\left(\frac{m h^{2}}{12}+\frac{m B}{k G h}\right) \frac{\omega^{2}}{c^{2}} \sin ^{2} \theta-\frac{m^{2} h^{2}}{12 k G} \omega^{2}}{1+\frac{B}{k G h} \frac{\omega^{2}}{c^{2}} \sin ^{2} \theta-\frac{m h}{12 k G} \omega^{2}} .
$$

Tämä tulos on esitetty lähteen [1] kaavassa (9.90), sillä erolla, että siinä $k=1$.

Tärkeä käytännön sovellus on sandwich laatta. Esimerkiksi kuvan 2 sandwich laatan, jonka pintakerrokset ovat ohuet ja samanlaiset, taivutusjäykkyys, leikkausjäykkyys, pintamassa ja rotaatiohitaus voidaan arvioida kaavoilla

$$
B=\frac{E_{s} d^{2} t}{2\left(1-v_{s}^{2}\right)}, S=G_{c} d, m=2 \rho_{s} t+\rho_{c}(d-t), J=\frac{\rho_{s} t d^{2}}{2}+\frac{\rho_{c}(d-t)^{3}}{12},
$$

joissa alaindeksit $s$ ja $c$ viittaavat pinta- (surface) ja ydinkerrokseen (core).

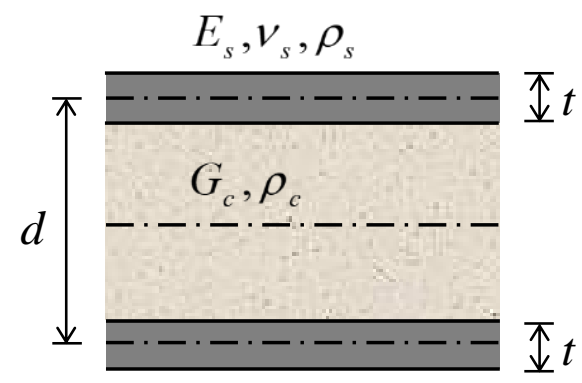

Kuva 2. Yksinkertaisen sandwich laatan poikkileikkaus

\section{Yksittäisen laatan ääneneristävyys}

\section{Laatan äänenläpäisevyyskerroin}

Tarkastellaan laattaa, jonka ylä- ja alapuolella on yleisessä tapauksessa eri nesteet, jotka identifioidaan alaindekseillä $-\mathrm{ja}+$. Asetetaan koordinaatiston origo laatan yläpintaan, jolloin $z_{-}=0$. Nesteistä laattaan kohdistuva jakautunut kuorma muodostuu sen ylä- ja alapintoihin $z=0$ ja $z=z_{+}$kohdistuvista paineista seuraavasti

$$
\mathrm{q}(x, y, t)=\mathrm{p}_{-}(x, y, 0, t)-\mathrm{p}_{+}\left(x, y, z_{+}, t\right) .
$$

Käyttäen kaavoja (28), (33), (32) ja (36) saadaan

$$
\mathrm{q}(x, y, t)=\left(\hat{\mathrm{p}}_{I}+\hat{\mathrm{p}}_{R}-\hat{\mathrm{p}}_{+} e^{-\mathrm{j} k_{z} z_{+}}\right) e^{\mathrm{j}\left(\omega t-k_{x} x-k_{y} y\right)}=\hat{\mathrm{q}} e^{\mathrm{j}\left(\omega t-k_{x} x-k_{y} y\right)},
$$

missä kuorma-amplitudi on

$$
\hat{\mathrm{q}}=2 \hat{\mathrm{p}}_{I}-\left(\frac{\rho_{-} c_{-}}{\cos \theta_{-}}+\frac{\rho_{+} c_{+}}{\cos \theta_{+}}\right) \hat{\mathrm{\textrm {w }}} .
$$

Sijoittamalla tämä yhtälöön (74) saadaan yhtälö

$$
\left(\mathrm{Z}^{*}+\frac{\rho_{-} c_{-}}{\cos \theta_{-}}+\frac{\rho_{+} c_{+}}{\cos \theta_{+}}\right) \hat{\dot{\mathrm{w}}}=2 \hat{\mathrm{p}}_{I},
$$

jonka ratkaisu kompleksiselle taipumanopeuden amplitudille on 


$$
\hat{\mathrm{w}}=\frac{2 \hat{\mathrm{p}}_{I}}{\mathrm{Z}^{*}+\frac{\rho_{-} c_{-}}{\cos \theta_{-}}+\frac{\rho_{+} c_{+}}{\cos \theta_{+}}} .
$$

Läpäisseen aallon ( $T$ transmitted wave) kompleksinen paine laatan alapinnalla on $\mathrm{p}_{T}(x, y, t)=\mathrm{p}_{+}\left(x, y, z_{+}, t\right)$. Kaavoja (33) ja (36) käyttäen sen amplitudille saadaan

$$
\hat{\mathrm{p}}_{T}=\frac{\rho_{+} c_{+}}{\cos \theta_{+}} \hat{\dot{\mathrm{w}}}
$$

Sijoittamalla siihen taipumanopeuden amplitudi (97) saadaan tulos

$$
\hat{\mathrm{p}}_{T}=\frac{\hat{\mathrm{p}}_{I}}{\frac{1}{2}+\frac{1}{2} \frac{\rho_{-} c_{-}}{\rho_{+} c_{+}} \frac{\cos \theta_{+}}{\cos \theta_{-}}+\mathrm{Z}^{*} \frac{\cos \theta_{+}}{2 \rho_{+} c_{+}}} .
$$

Laatan äänenläpäisevyyskertoimelle vinosti kohtaavalle ääniaallolle saadaan nyt kaavan (55) perusteella

$$
\tau_{L}=\frac{\rho_{-} c_{-}}{\rho_{+} c_{+}} \frac{\cos \theta_{+}}{\cos \theta_{-}} \frac{1}{\left|\frac{1}{2}+\frac{1}{2} \frac{\rho_{-} c_{-}}{\rho_{+} c_{+}} \frac{\cos \theta_{+}}{\cos \theta_{-}}+Z^{*} \frac{\cos \theta_{+}}{2 \rho_{+} c_{+}}\right|^{2}},
$$

missä $\rho_{-}, c_{-}, \rho_{+}$ja $c_{+}$ovat laatan ylä- ja alapuoleisen nesteen tiheydet ja äänen nopeudet sekä $\theta$ ja $\theta_{+}$ovat kohtaavan ja läpäisseen aallon suuntakulmat. Jos laatan molemmilla puolilla on ilmaa, $\rho_{-}=\rho_{+}=\rho$ ja $c_{-}=c_{+}=c$, missä $\rho$ ja $c$ ovat ilman tiheys ja äänen nopeus, äänenläpäisevyyskertoimen lauseke (100) yksinkertaistuu muotoon

$$
\tau_{\llcorner}=\frac{1}{\left|1+\mathrm{Z}^{*} \frac{\cos \theta}{2 \rho c}\right|^{2}} .
$$

Lauseketta (101) (tai (100)) käyttäen voidaan määrittää erilaisten laattojen äänenläpäisevyyskerroin $\tau_{\angle}$ sijoittamalla siihen kyseisen laatan aaltoimpedanssin lauseke. Edellä todettiin, että yleisessä tapauksessa äänenläpäisevyyskerroin $\tau_{L}$ riippuu molemmista suuntakulmista $\phi$ ja $\theta$. Näin esimerkiksi ortotrooppisen Kirchhoff-laatan tapauksessa todella käykin, koska sen aaltoimpedanssin lausekkeessa (80) esiintyvät aaltoluvut $k_{x}$ ja $k_{y}$, jotka riippuvat kaavojen (20a) ja (20b) perusteella kulmasta $\phi$. Tässä tapauksessa laatan äänenläpäisevyyskerroin $\tau$ diffuusille kentälle lasketaan kaavalla (64) käyttäen numeerista integrointia kahdessa suunnassa. Isotrooppisten Kirchhoff- ja Reissner-Mindlinlaattojen tapauksessa äänenläpäisevyyskerroin $\tau_{\angle}$ riippuu vain kulmasta $\theta$ ja laatan äänenläpäisevyyskerroin $\tau$ voidaan laskea nopeammin kaavalla (65) käyttäen numeerista integrointia yhdessä suunnassa. Laatan ääneneristävyys saadaan lopuksi kaavalla (66).

\section{Isotrooppisen Kirchhoff-laatan äänenläpäisevyyskerroin}

Tarkastellaan hieman yksityiskohtaisemmin isotrooppisen Kirchhoff-laatan äänenläpäisevyyskertoimen $\tau_{\angle}$ määrittämistä. Sijoittamalla aaltoimpedanssin lauseke (82) kaavaan (101), laatan äänenläpäisevyyskertoimelle lauseke 


$$
\tau_{L}=\frac{1}{\left|1+\mathrm{j}\left[m \omega-\frac{\mathrm{B}}{\omega}\left(\frac{\omega}{c}\right)^{4} \sin ^{4} \theta\right] \frac{\cos \theta}{2 \rho c}\right|^{2}} .
$$

Muokataan lauseketta (102) sijoittamalla siihen kompleksisen taivutusjäykkyyden lauseke (83). Saadaan tulos

$$
\tau_{<}=\frac{1}{\left.\left[1+\eta \frac{B}{\omega}\left(\frac{\omega}{c}\right)^{4} \sin ^{4} \theta \frac{\cos \theta}{2 \rho c}\right]^{2}+\left\{m \omega-\frac{B}{\omega}\left(\frac{\omega}{c}\right)^{4} \sin ^{4} \theta\right] \frac{\cos \theta}{2 \rho c}\right\}^{2}},
$$

joka on reaalimuodossa. Tämä voidaan vielä saattaa muotoon

$$
\tau_{L}=\frac{1}{\left(1+\eta \frac{f^{2}}{f_{c}^{2}} \sin ^{4} \theta \frac{\pi m f}{\rho c} \cos \theta\right)^{2}+\left[\left(1-\frac{f^{2}}{f_{c}^{2}} \sin ^{4} \theta\right) \frac{\pi m f}{\rho c} \cos \theta\right]^{2}},
$$

missä $f=\omega / 2 \pi$ on taajuus ja vakiota

$$
f_{c}=\frac{c^{2}}{2 \pi} \sqrt{\frac{m}{B}}
$$

kutsutaan kriittiseksi taajuudeksi. Tulos (104) hieman eri muodossa on esitetty lähteessä [1] numerolla (9.95). Havaitaan, että taajuudella

$$
f=\frac{f_{c}}{\sin ^{2} \theta}
$$

äänenläpäisevyyskerroin on

$$
\tau_{\angle}=\frac{1}{\left(1+\eta \frac{\pi m f_{c}}{\rho c} \frac{\cos \theta}{\sin ^{2} \theta}\right)^{2}}
$$

ja vaimentamattomassa tapauksessa $\eta=0$ se on $\tau_{\angle}=1$. Tämä merkitsee, että taajuuden lähestyessä arvoa (106) äänenläpäisevyyskerroin lähestyy ykköstä ja ääneneristävyys vastaavasti nollaa. Ilmiötä kutsutaan koinsidenssiksi.

Tarkastellaan esimerkkinä lähteessä [1] tarkasteltua lasilaattaa, jonka paksuus, kimmomoduuli, Poissonin luku, häviökerroin ja tiheys ovat $h=4,76 \cdot 10^{-3} \mathrm{~m}\left(3 / 16^{\prime \prime}\right)$, $E=6,76 \cdot 10^{10} \mathrm{~N} / \mathrm{m}^{2}, v=0,33, \eta=1 \cdot 10^{-3}$ ja $\rho_{p}=2500 \mathrm{~kg} / \mathrm{m}^{3}$. Ilman tiheydelle ja äänen nopeudelle ilmassa käytetään arvoja $\rho=1,21 \mathrm{~kg} / \mathrm{m}^{3}$ ja $c=343 \mathrm{~m} / \mathrm{s}$. Taivutus-jäykkyydelle ja kriittiselle taajuudelle saadaan $B=681,8 \mathrm{Nm}$ ja $f_{c}=2473,7 \mathrm{~Hz}$. Kuvassa 3 on esitetty kaavoja (104) ja (59) käyttäen laskettu lasilaatan ääneneristävyys $R_{\angle}$ tulokulmilla $\theta=0^{\circ}, \theta=45^{\circ}, \theta=85^{\circ}$ taajuuden funktiona. Koinsidenssitaajuudet (106) tulokulmilla $\theta=45^{\circ}$ ja $\theta=85^{\circ}$ ovat vastaavasti $4950 \mathrm{~Hz}$ ja $2490 \mathrm{~Hz}$. Kaavoja (107) ja (59) käyttäen saadaan laatan tulokulmia $\theta=45^{\circ}$ ja $\theta=85^{\circ}$ vastaaviksi ääneneristävyyksiksi $R_{\measuredangle}$ koinsidenssitaajuudella arvot $2,38 \mathrm{~dB}$ ja $0,17 \mathrm{~dB}$, jotka ovat pieniä. Laskettiin myös laatan ääneneristävyys $R$ diffuusille kentälle taajuuden funktiona, soveltamalla kaavaa (65) ja numeerista integrointia. Tulos on piirretty täydellä viivalla kuvaan 3. Lähteen [1] kuvassa 9.19 esitetyt käyrät, jotka on piirretty harvemmalla pistejaolla, ovat hieman epätarkempia. 
Kuvassa 4 on konstruoitu kohdissa 3.4 ja 3.5 esitetyllä tavalla lasilaatan ääneneristysluku, jolle saatiin arvo $R_{w}=28 \mathrm{~dB}$.

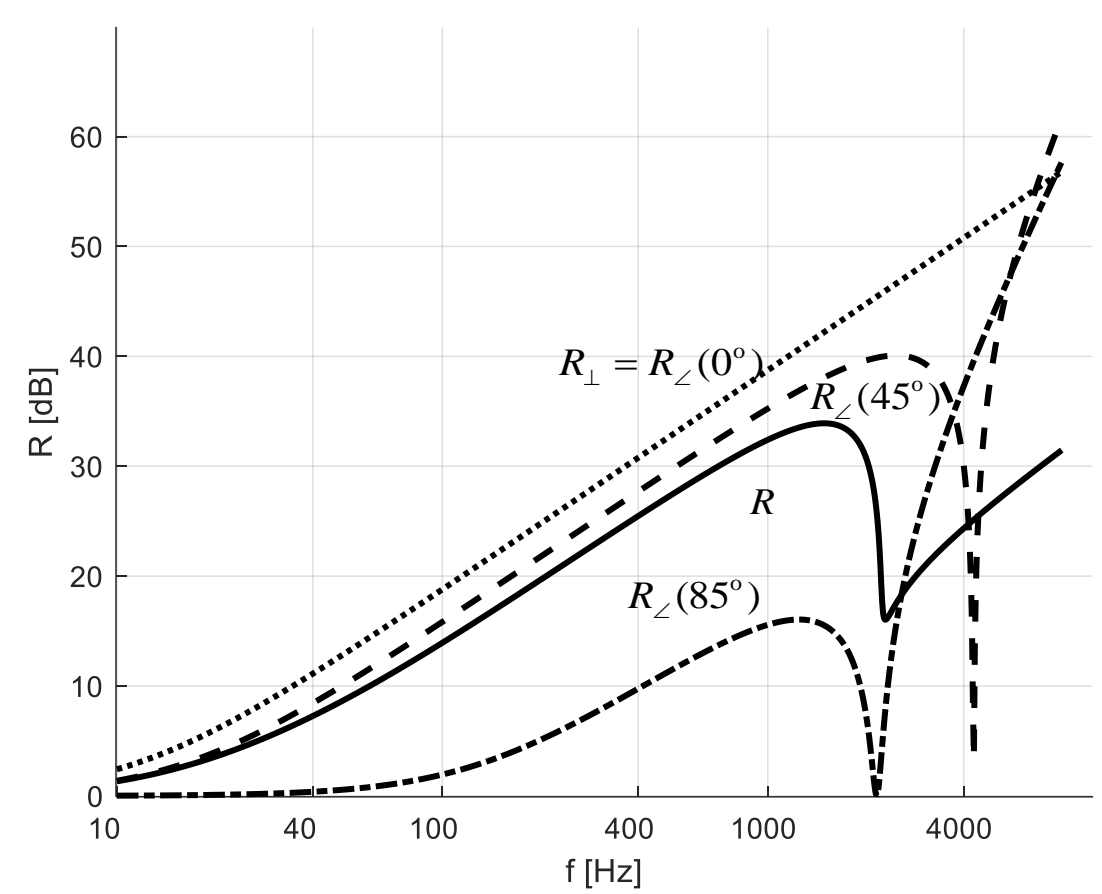

Kuva 3. 3/16" (4,76 mm) paksuisen lasilaatan ääneneristävyys $R_{<}$taajuuden funktiona eri tulokulmilla: $\theta=0^{\circ} ; \theta=45^{\circ} ; \theta=85^{\circ}$ sekä ääneneristävyys $R$.

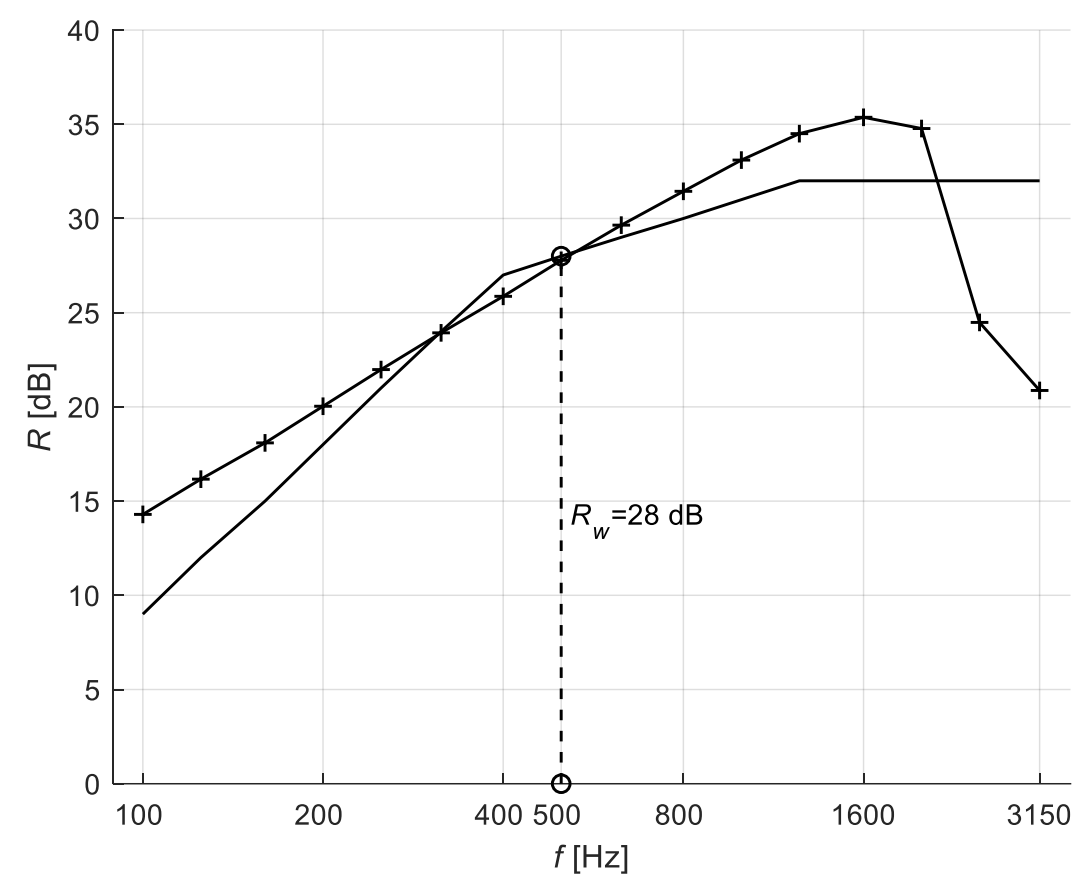

Kuva 4. 3/16" paksuisen lasilaatan laskennallinen ääneneristävyyskäyrä +, vertailukäyrä - ja niiden avulla laskettu ääneneristysluku $R_{w}$. 


\section{Massalaki}

Taajuuden ollessa kriittiseen arvoon nähden pieni $f \approx f_{c}$, laatan äänenläpäisevyys-kertoimelle (104) saadaan

$$
\tau_{<}^{m}=\frac{1}{1+\left(\frac{\pi m f}{\rho c} \cos \theta\right)^{2}}
$$

ja ääneneristävyydelle

$$
R_{\llcorner}^{m}=10 \lg \left[1+\left(\frac{\pi m f}{\rho c} \cos \theta\right)^{2}\right] .
$$

Havaitaan, että nämä suureet eivät riipu laatan taivutusjäykkyydestä vaan pelkästään sen pintamassasta $m$. Puhutaan massalain mukaisista suureista ja symboleihin on lisätty yläindeksi $m$ muistuttamaan tästä. Kaavat (108) ja (109) antavat siis laatan massalain mukaiset äänenläpäisevyyskertoimen ja ääneneristävyyden. Massalain yhteydessä on myös mahdollista johtaa [3] analyyttiset kaavat laatan äänenläpäisevyyskertoimelle ja ääneneristävyydelle diffuusin kentän tapauksessa. Esitetään kaava (108) muodossa

$$
\tau_{\angle}^{m}(\theta)=\frac{1}{1+a^{2} \cos ^{2} \theta},
$$

missä on käytetty lyhennysmerkintää

$$
a=\frac{\pi f m}{\rho c}
$$

Soveltamalla kaavaa (65) saadaan

$$
\tau^{m}=\frac{2}{\sin ^{2} \bar{\theta}} \int_{0}^{\bar{\theta}} \frac{\sin \theta \cos \theta}{1+a^{2} \cos ^{2} \theta} d \theta
$$

ja suorittamalla integrointi, massalain mukaiselle äänenläpäisevyyskertoimelle $\tau^{m}$ tulos

$$
\tau^{m}=\frac{1}{a^{2} \sin ^{2} \bar{\theta}} \ln \frac{1+a^{2}}{1+a^{2} \cos ^{2} \bar{\theta}} .
$$

Vastaavalle ääneneristävyydelle saadaan tulos

$$
R^{m} \equiv 10 \lg \frac{1}{\tau^{m}}=10 \lg \frac{a^{2} \sin ^{2} \bar{\theta}}{\ln \frac{1+a^{2}}{1+a^{2} \cos ^{2} \bar{\theta}}} .
$$

Kuvassa 5 on esitetty isotrooppisen laatan ääneneristävyys $R_{\perp}=R_{\llcorner}\left(0^{\circ}\right)$ kohtisuoraan kohtaavalle ääniaallolle sekä kaavalla (114) lasketut vastaavat ääneneristävyydet $R^{m}$ diffuusille kentälle, kun $\bar{\theta}=78^{\circ}$ ja $\bar{\theta}=90^{\circ}$, taajuuden ja massan tulon $\mathrm{fm}$ funktiona. Vastaava kuva on lähteissä [1], [3] ja [4]. Yleensä $a \approx 1$, jolloin

$$
R^{m} \approx 10 \lg \frac{a^{2} \sin ^{2} \bar{\theta}}{\ln \frac{1}{\cos ^{2} \bar{\theta}}}=10 \lg a^{2}-10 \lg \frac{\sin ^{2} \bar{\theta}}{\ln \frac{1}{\cos ^{2} \bar{\theta}}} .
$$

Sijoittamalla tähän $\bar{\theta}=78^{\circ}$ saadaan

$$
R^{m} \approx 10 \lg \left(\frac{\pi f m}{\rho c}\right)^{2}-5,16 .
$$

Laatan ääneneristävyydelle $R_{\perp}$ saadaan kaavoilla (59) ja (104) 


$$
R_{\perp} \equiv R_{\llcorner}\left(0^{\circ}\right)=10 \lg \left[1+\left(\frac{\pi m f}{\rho c}\right)^{2}\right] \approx 10 \lg \left(\frac{\pi m f}{\rho c}\right)^{2} .
$$

Käytettiin hyväksi tietoa että $a \approx 1$. Näin saadaan yhteys

$$
R^{m} \approx R_{\perp}-5,16 \text {. }
$$

Tähän kaavaan perustuu yleisessä käytössä oleva sääntö, että massalain mukainen (kulmaa $\bar{\theta}=78^{\circ}$ käyttäen laskettu) ääneneristävyys $R^{m}$ diffuusille kentälle on noin $5 \mathrm{~dB}$ pienempi kuin kohtisuoraan kohtaavan aallon ääneneristävyys.

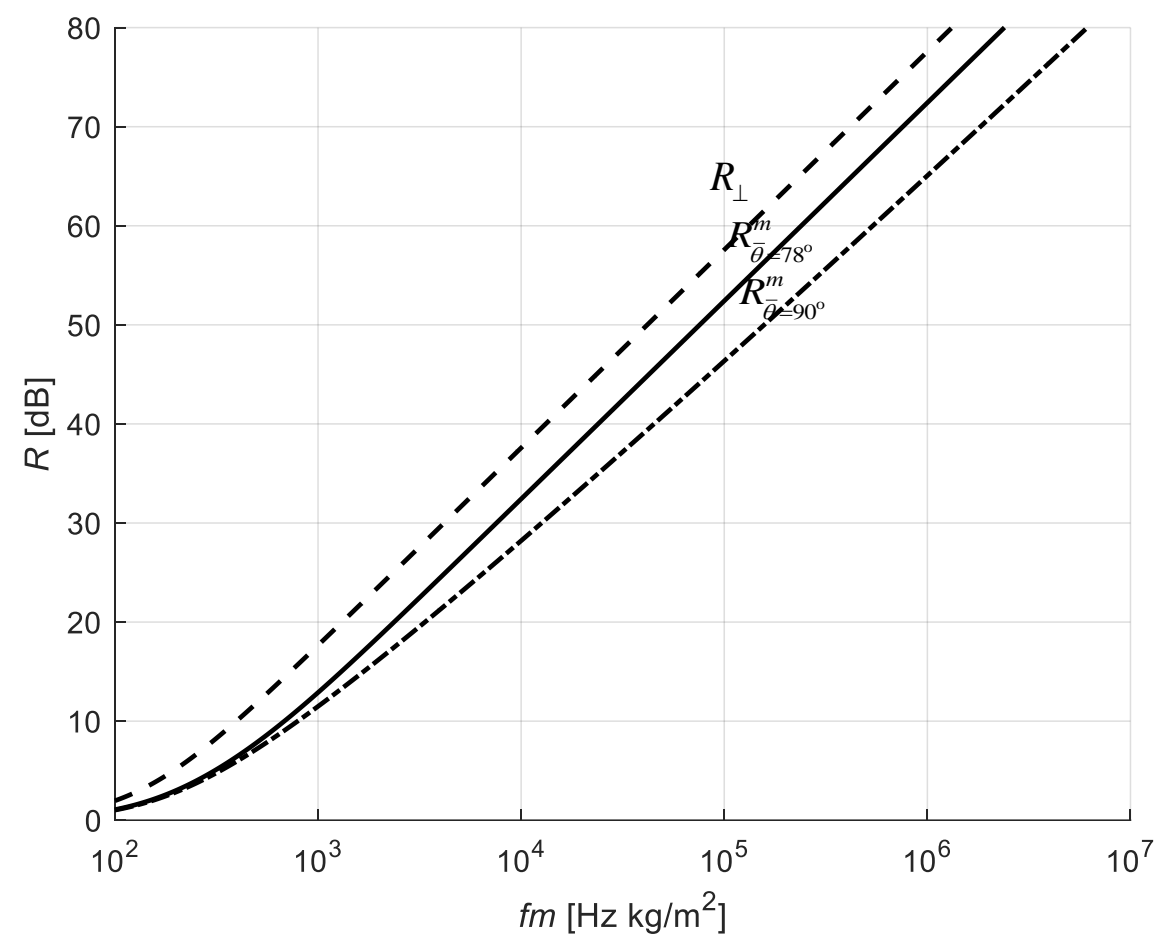

Kuva 5. Käyrät ääneneristävyyden määrittämiseksi, kun massalaki on voimassa eli $f / f_{c} \approx 1$. Kohtisuoraan kohtaavan aallon ääneneristävyys $R_{\perp}$ ja massalain mukainen ääneneristävyys $R^{m}$ diffuusille kentälle laskettuna kaavalla (114), kun $\bar{\theta}=78^{\circ}$ ja kun $\bar{\theta}=90^{\circ}$.

\section{Käyrästö isotrooppisen laatan ääneneristävyyden määrittämiseksi}

Konstruoidaan lopuksi akustiikan oppikirjoissa [1], [3] esiintyvä käyrästö, jonka avulla isotrooppisen Kirchhoff-laatan ääneneristävyys $\tau$ diffuusille kentälle voidaan määrittää graafisesti. Laatan äänenläpäisevyyskertoimelle kohtisuoraan kohtaavalle $\left(\theta=0^{\circ}\right)$ ääniaallolle saadaan kaavalla (104)

$$
\tau_{\perp} \equiv \tau_{\angle}\left(0^{\circ}\right)=\frac{1}{1+\left(\frac{\pi m f}{\rho c}\right)^{2}}
$$

ja sen arvolle kriittisellä taajuudella 


$$
\tau_{\perp}^{c} \equiv \tau_{\perp}\left(f_{c}\right)=\frac{1}{1+\left(\frac{\pi m f_{c}}{\rho c}\right)^{2}} .
$$

Kaavojen (104) ja (120) perusteella kertoimien $\tau_{\llcorner}(\theta)$ ja $\tau_{\perp}^{c}$ suhde saa muodon

$$
\frac{\tau_{\angle}(\theta)}{\tau_{\perp}^{c}}=\frac{1+\left(\frac{\rho c}{\pi m f_{c}}\right)^{2}}{\left(\frac{\rho c}{\pi m f_{c}}+\eta \frac{f^{3}}{f_{c}^{3}} \sin ^{4} \theta \cos \theta\right)^{2}+\left[\left(\frac{f}{f_{c}}-\frac{f^{3}}{f_{c}^{3}} \sin ^{4} \theta\right)^{2} \cos ^{2} \theta\right.} .
$$

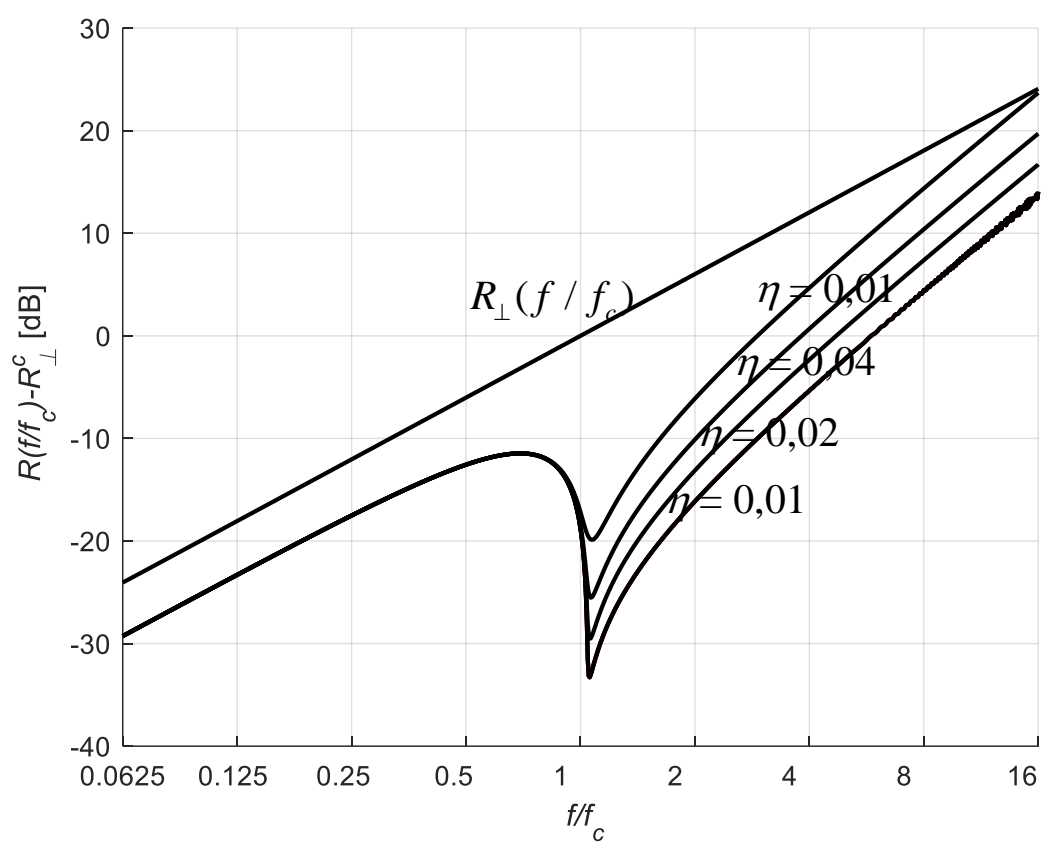

Kuva 6. Käyrästö isotrooppisen Kirchhoff-laatan ääneneristävyyden määrittämiseksi taajuudella $f$ eri häviökertoimilla $\eta$.

Olettamalla, että

$$
\frac{\rho c}{\pi m f_{c}} \approx 1
$$

joka vastaa edellä käytettyä oletusta $a \approx 1$, kaava (121) yksinkertaistuu muotoon

$$
\frac{\tau_{\perp}(\theta)}{\tau_{\perp}^{c}}=\frac{1}{\left[\left(\eta \frac{f^{3}}{f_{c}^{3}} \sin ^{4} \theta\right)^{2}+\left(\frac{f}{f_{c}}-\frac{f^{3}}{f_{c}^{3}} \sin ^{4} \theta\right)^{2}\right] \cos ^{2} \theta} .
$$

Koska $\tau_{\perp}^{c}$ on vakio, voidaan vastaava suhde $\tau / \tau_{\perp}^{c}$ määrittää soveltamalla kaavaa (65) ja numeerista integrointia. Laatan ääneneristävyydelle diffuusille kentälle saadaan

$$
R=10 \log \frac{1}{\tau}=10 \log \frac{\tau_{\perp}^{c}}{\tau}+10 \log \frac{1}{\tau_{\perp}^{c}}=10 \log \frac{\tau_{\perp}^{c}}{\tau}+R_{\perp}^{c},
$$


missä

$$
R_{\perp}^{c}=10 \log \frac{1}{\tau_{\perp}^{c}}=10 \lg \left[1+\left(\frac{\pi m f_{c}}{\rho c}\right)^{2}\right]
$$

on kriittisellä taajuudella määritetty kohtisuoraan kohtaavan aallon ääneneristävyys. Näiden erotus on

$$
R-R_{\perp}^{c}=10 \log \frac{\tau_{\perp}^{c}}{\tau}
$$

Kaavoja (123), (65) ja (126) soveltaen voidaan koordinaatistoon, jonka abskissa ja ordinaatta ovat $f / f_{c}$ ja $R-R_{\perp}^{c}$ konstruoida käyriä. Nämä käyrät riippuvat ainoastaan suhteesta $f / f_{c}$ ja häviökertoimesta $\eta$. Käyrästö on esitetty kuvassa 6 ja se on laatan ja myös sitä ympäröivän nesteen ominaisuuksista riippumaton. Vastaava käyrästö on esitetty ilman johtoa lähteissä [1] ja [3].

\section{Ortotrooppinen laatta}

Sijoittamalla aaltoimpedanssin lauseke (80) kaavaan (101), saadaan ortotrooppisen Kirchhoff-laatan äänenläpäisevyyskertoimelle vinosti kohtaavalle ääniaallolle lauseke

$$
\tau_{L}=\frac{1}{\left|1+\mathrm{j}\left(m \omega-\frac{\mathrm{B}_{x} k_{x}^{4}+2 \mathrm{H} k_{x}^{2} k_{y}^{2}+\mathrm{B}_{y} k_{y}^{4}}{\omega}\right) \frac{\cos \theta}{2 \rho c}\right|^{2}} .
$$

Laatan äänenläpäisevyyskertoimen $\tau$ laskeminen diffuusille kentälle tapahtuu nyt numeerisesti kaavalla (64).

Tarkastellaan esimerkkinä kuvan 7 teräksistä aaltolevyä, jonka poikkileikkauksen keskiviivan yhtälö on

$$
z=a \sin \frac{\pi x}{l},
$$

missä $a$ on amplitudi ja $l$ puolijakson pituus. Lähteen [7] mukaan laatan taivutusjäykkyydet ovat

$$
B_{x}=\frac{l}{s} \frac{E h^{3}}{12\left(1-v^{2}\right)}, B_{y}=E I, \quad H=\frac{s}{l} \frac{E h^{3}}{12(1+v)},
$$

missä $h$ on levyn seinämän paksuus, $s$ puolijakson pituutta vastaava kaarenpituus ja $I$ poikkileikkauksen jäyhyysmomentti pituutta kohden. Jälkimmäiset voidaan määrittää likikaavoilla

$$
s \approx l\left[1+\frac{\pi^{2}}{4}\left(\frac{a}{l}\right)^{2}\right], \quad I \approx \frac{a^{2} h}{2}\left[1+\frac{\pi^{2}}{8}\left(\frac{a}{l}\right)^{2}\right] .
$$

Teräksen kimmomoduuli, Poissonin luku, tiheys ja häviökerroin ovat $E=2 \cdot 10^{11} \mathrm{~N} / \mathrm{m}^{2}$, $v=0,3, \rho_{s}=7700 \mathrm{~kg} / \mathrm{m}^{3}$ ja $\eta=10^{-3}$. Lisäksi $l=25 \mathrm{~mm}, a=10 \mathrm{~mm}$ levyn seinämän paksuus on $h=1 \mathrm{~mm}$. Kuvissa 8,9 ja 10 on esitetty aaltolevyn $R_{L}$ taajuuden $f$ funktiona suuntakulman $\phi$ arvoilla $0^{\circ}, 45^{\circ}$ ja $90^{\circ}$. Niihin on piirretty kohtaamiskulman $\theta$ arvoja $0^{\circ}, 25^{\circ}, 50^{\circ}$ ja $75^{\circ}$ vastaavat käyrät. Kuvassa 11 on esitetty aaltolevyn ja vertailun vuoksi saman paksuisen tasolevyn ääneneristävyys $R$ taajuuden $f$ funktiona. Aaltole- 
vyn ääneneristysluvun $R_{w}$ määrittämistä havainnollistaa kuva 12 . Sille saatiin arvo $R_{w}=22 \mathrm{~dB}$. Vastaavan tasolevyn ääneneristysluvun arvoksi tuli $R_{w}=28 \mathrm{~dB}$. Aaltolevy eristää siis ääntä huonommin kuin vastaava tasolevy.

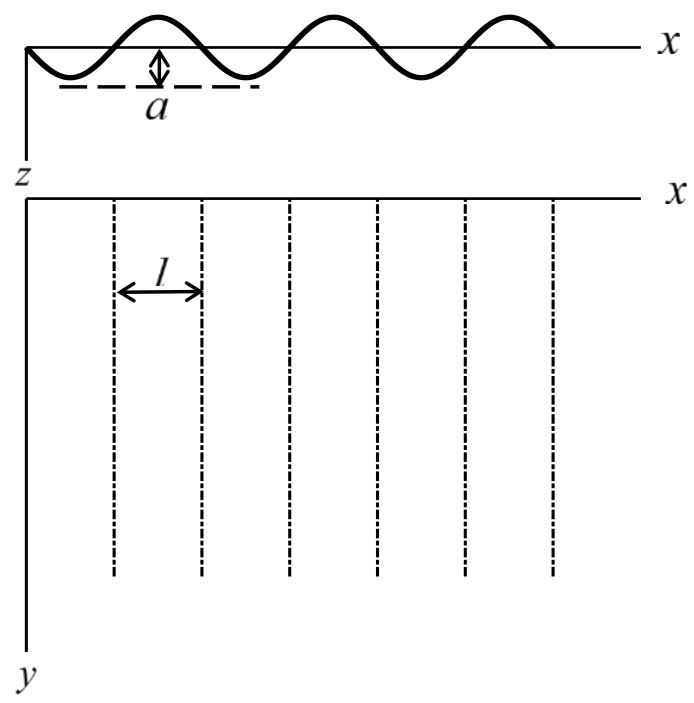

Kuva 7. Teräksinen aaltolevy

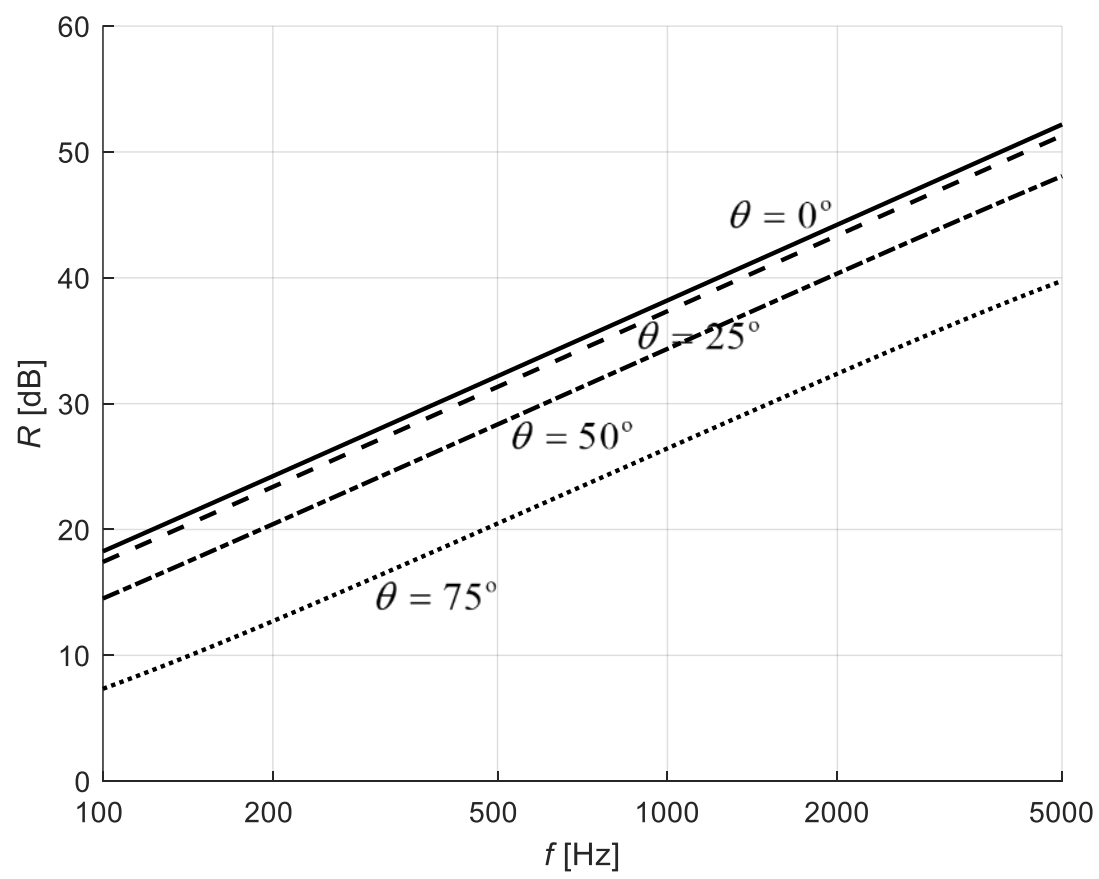

Kuva 8. Aaltolevyn ääneneristävyys $R_{\llcorner}$taajuuden $f$ funktiona, kun $\phi=0^{\circ}$ ja ja $\theta=0^{\circ}, 25^{\circ}$, $50^{\circ}, 75^{\circ}$. 


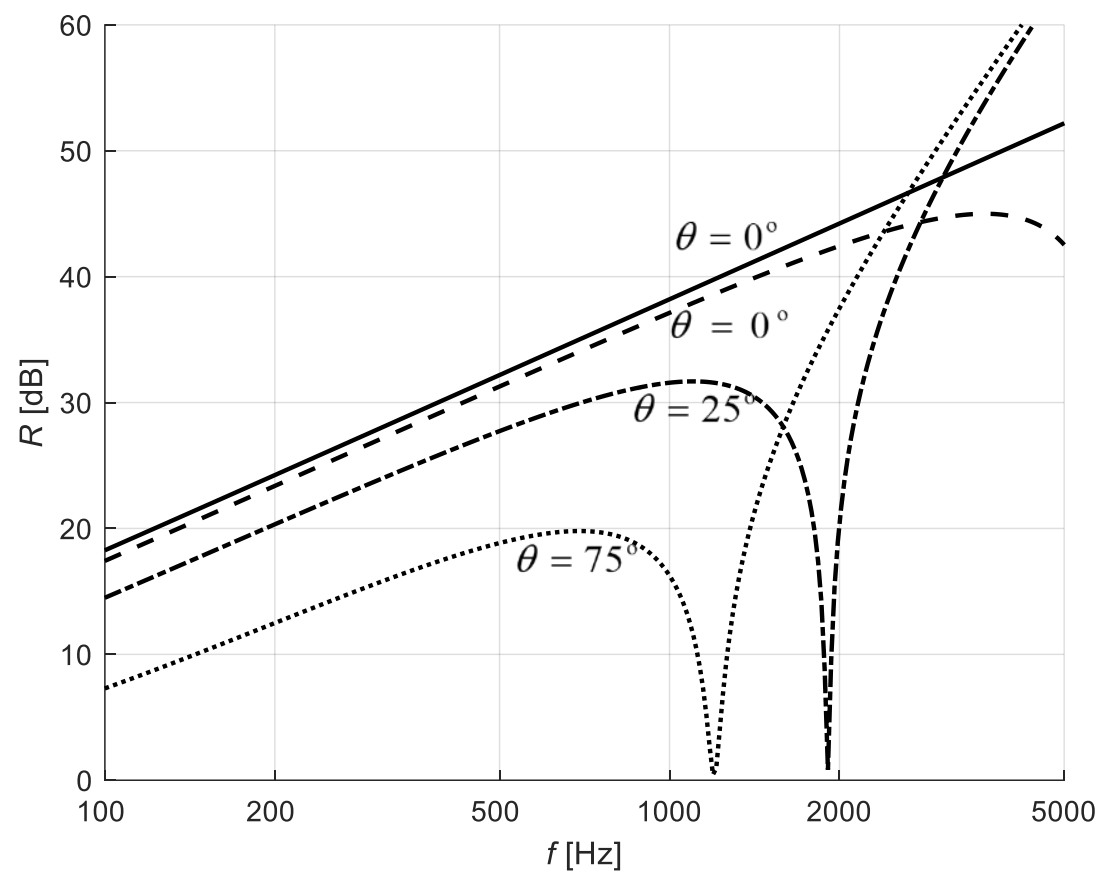

Kuva 9. Aaltolevyn ääneneristävyys $R_{\llcorner}$taajuuden $f$ funktiona, kun $\phi=45^{\circ}$ ja $\theta=0^{\circ}, 25^{\circ}$, $50^{\circ}, 75^{\circ}$.

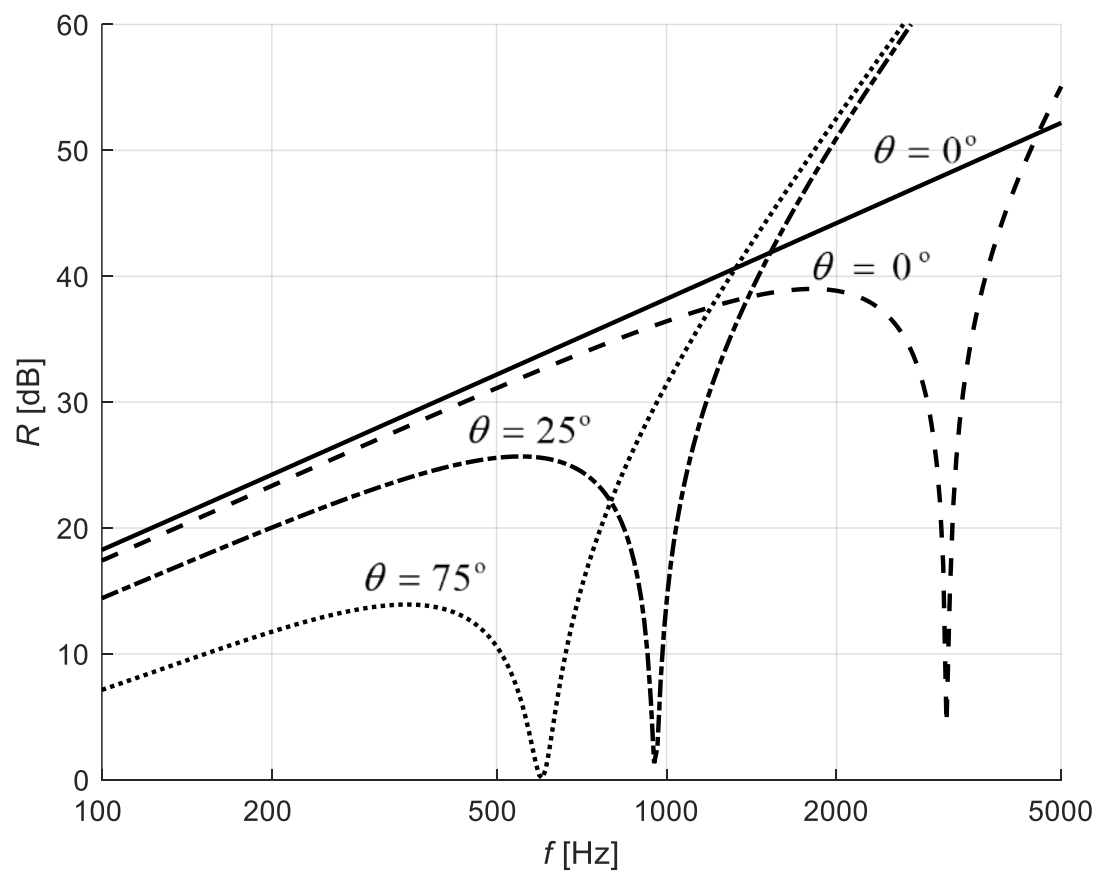

Kuva 10. Aaltolevyn ääneneristävyys $R_{\llcorner}$taajuuden $f$ funktiona, kun $\phi=90^{\circ}$ ja $\theta=0^{\circ}, 25^{\circ}$, $50^{\circ}, 75^{\circ}$. 


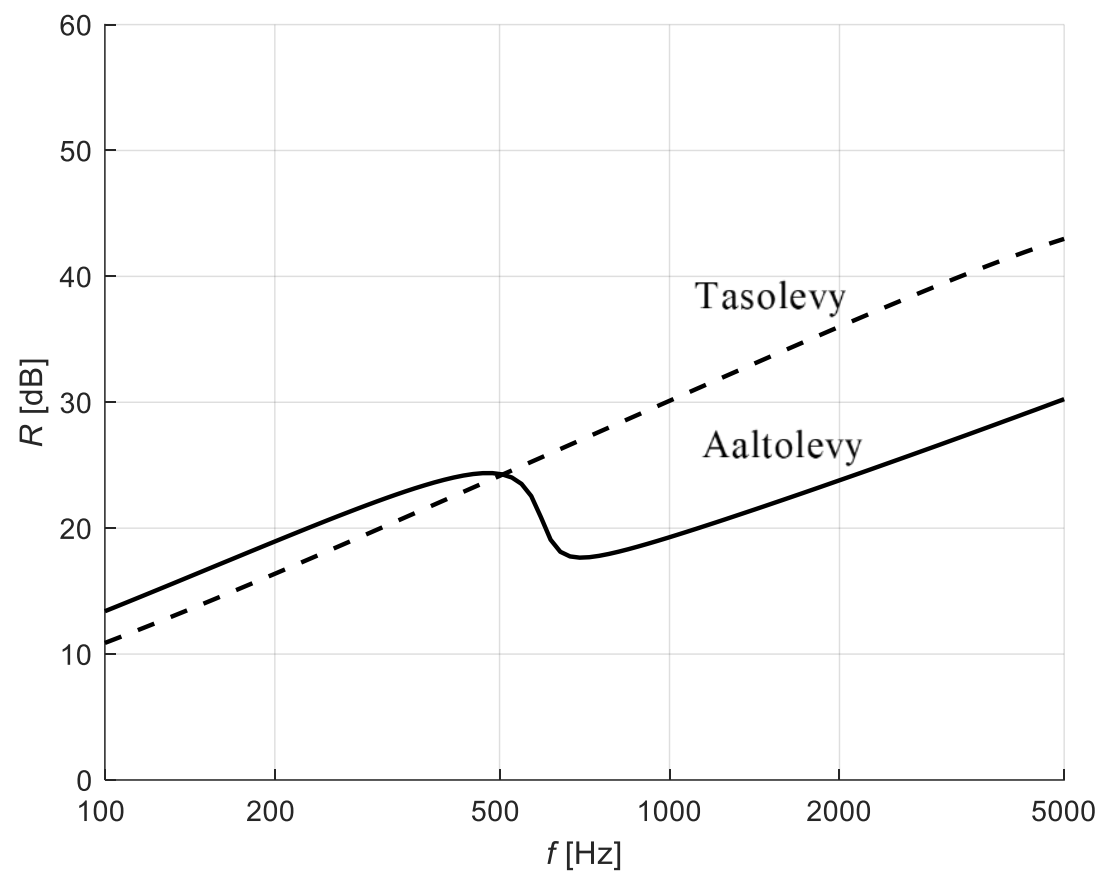

Kuva 11. Aaltolevyn ja saman paksuisen tasolevyn ääneneristävyys $R$ taajuuden $f$ funktiona

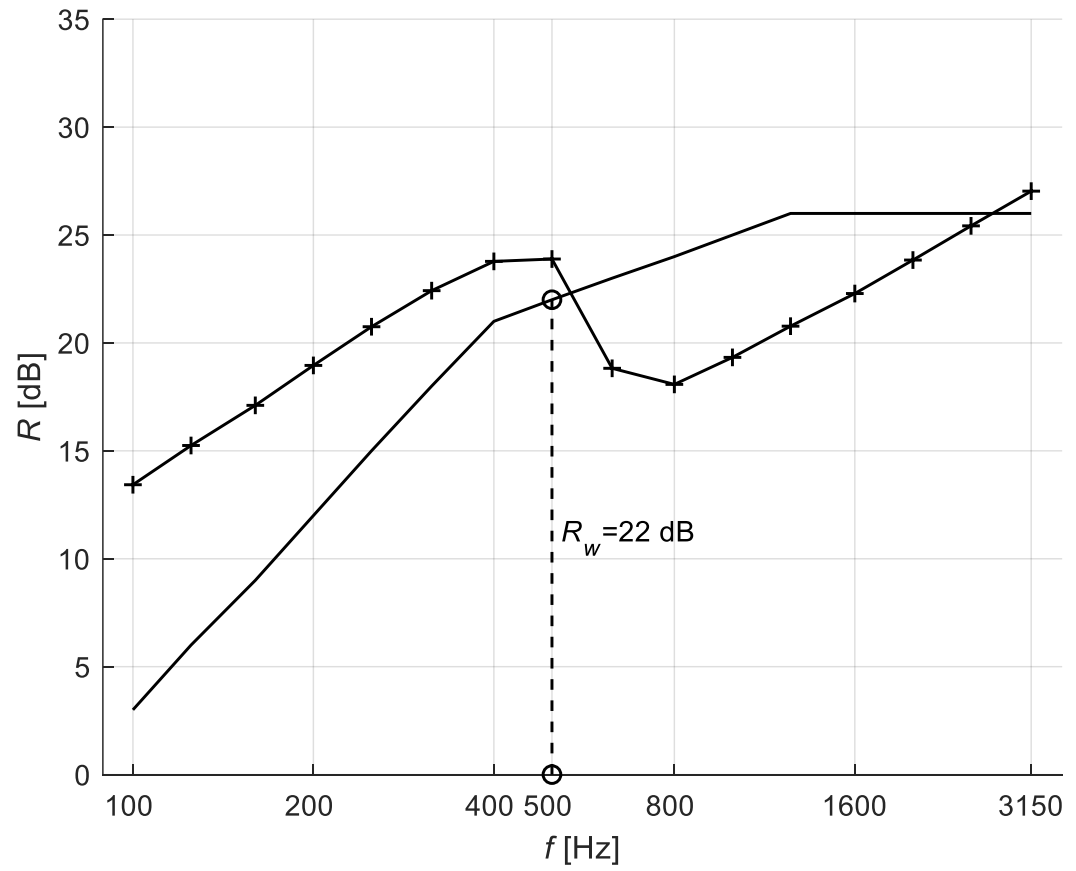

Kuva 12. Aaltolevyn laskennallinen ääneneristävyyskäyrä + , vertailukäyrä - ja niiden avulla laskettu ääneneristysluku $R_{w}$. 


\section{Laatoista ja niiden välisistä nestekerroksista koostuva rakenne}

\section{Rakenne}

Tarkastellaan kuvan 13 laatoista $i=1, \cdots, n$ ja niiden välisistä nestekerroksista $i=1, \cdots, n-1$ koostuvaa tasorakennetta. Ylä- ja alapuolen suureille käytetään alaindeksejä 0 ja $n$. Tarkastelussa $x, y$-taso yhtyy ylimmän laatan 1 yläpintaan, joten $z_{1-}=0$.

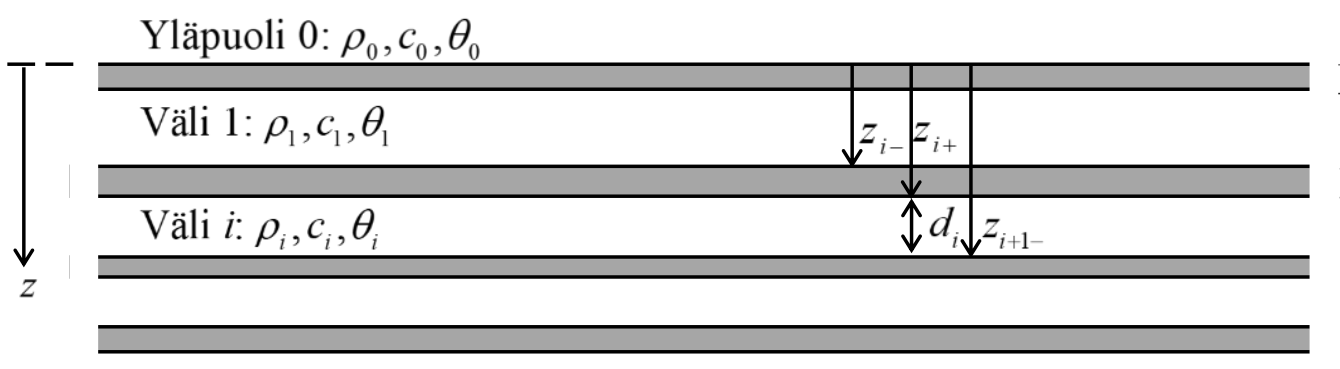

Laatta 1

Laatta $i$

Alapuoli $n: \rho_{n}, c_{n}, \theta_{n}$

Kuva 13. Laattarakenne

Laattojen $i=1, \cdots, n$ kompleksisten kuorma- ja taipuma-amplitudien $\hat{\mathrm{q}}_{i}$ ja $\hat{\mathrm{w}}_{i}$ välillä on yhtälöä (74) vastaten yhtälöt

$$
\mathrm{Z}_{i}^{*} \hat{\dot{\mathrm{w}}}_{i}=\hat{\mathrm{q}}_{i}, i=1, \cdots, n,
$$

missä $\mathrm{Z}_{i}^{*}$ on laatan $i$ aaltoimpedanssi.

\section{Laattojen kompleksiset kuorma-amplitudit}

Tarkastellaan ensin laattaa 1 , jonka ylä- ja alapuolella olevat nesteet ovat 0 ja 1 . Laatan jakautunut kuorma muodostuu sen ylä- ja alapintaan kohdistuvista paineista seuraavasti

$$
\begin{aligned}
\mathrm{q}_{1}(x, y, t) & =\mathrm{p}_{0}(x, y, 0, t)-\mathrm{p}_{1}\left(x, y, z_{1+}, t\right) \\
& =\left(\hat{\mathrm{p}}_{I}+\hat{\mathrm{p}}_{R}-\hat{\mathrm{p}}_{A 1} e^{-\mathrm{j} k_{z 1} z_{1+}}-\hat{\mathrm{p}}_{B 1} e^{\mathrm{j} k_{z 1} z_{1+}}\right) e^{\mathrm{j}\left(\omega t-k_{x} x-k_{y} y\right)} .
\end{aligned}
$$

Soveltaen kaavoja (32) ja (43) saadaan tästä

$$
\mathrm{q}_{1}(x, y, t)=\hat{\mathrm{q}}_{1} e^{\mathrm{j}\left(\omega t-k_{x} x-k_{y} y\right)},
$$

missä kuorma-amplitudi on

$$
\hat{\mathrm{q}}_{1}=2 \hat{\mathrm{p}}_{I}-\left(\frac{\rho_{0} c_{0}}{\cos \theta_{0}}-\mathrm{j} \frac{\rho_{1} c_{1}}{\cos \theta_{1}} \cot k_{z 1} d_{1}\right) \hat{\mathrm{w}}_{1}-\mathrm{j} \frac{\rho_{1} c_{1}}{\cos \theta_{1}} \cot k_{z 1} d_{1} \hat{\mathrm{w}}_{2} .
$$

Tarkastellaan sitten laattaa $i$, jonka ylä- ja alapuolella olevat nesteet ovat $i-1$ ja $i$. Laatan jakautunut kuorma muodostuu sen ylä- ja alapintaan kohdistuvista paineista seuraavasti

$$
\begin{aligned}
\mathrm{q}_{i}(x, y, t) & =\mathrm{p}_{i-1}\left(x, y, z_{i-} t\right)-\mathrm{p}_{i}\left(x, y, z_{i+} t\right) \\
& =\left(\mathrm{p}_{A i-1} e^{-\mathrm{j} k_{z i-1} z_{i-}}+\mathrm{p}_{B i-1} e^{\mathrm{j} k_{z i-1} z_{i-}}-\mathrm{p}_{A i} e^{-\mathrm{j} k_{z i} z_{i+}}-\mathrm{p}_{B i} e^{\mathrm{j} k_{z i} z_{i+}}\right) e^{\mathrm{j}\left(\omega t-k_{x} x-k_{y} y\right)} .
\end{aligned}
$$

Soveltaen kaavoja (43) saadaan tästä

missä kuorma-amplitudi on

$$
\mathrm{q}_{i}(x, y, t)=\hat{\mathrm{q}}_{i} e^{\mathrm{j}\left(\omega t-k_{x} x-k_{y} y\right)},
$$




$$
\begin{aligned}
& \hat{\mathrm{q}}_{i}=-\frac{\mathrm{j}}{\sin k_{z i-1} d_{i-1}} \frac{\rho_{i-1} c_{i-1}}{\cos \theta_{i-1}} \hat{\mathrm{w}}_{i-1} \\
& +\mathrm{j}\left(\frac{\rho_{i-1} c_{i-1}}{\cos \theta_{i-1}} \cot k_{z i-1} d_{i-1}+\frac{\rho_{i} c_{i}}{\cos \theta_{i}} \cot k_{z i} d_{i}\right) \hat{\dot{\mathrm{w}}}_{i} \\
& -\frac{\mathrm{j}}{\sin k_{z i} d_{i}} \frac{\rho_{i} c_{i}}{\cos \theta_{i}} \hat{\mathrm{w}}_{i+1}
\end{aligned}
$$

Tarkastellaan lopuksi laattaa $n$, jonka ylä- ja alapuolella olevat nesteet ovat $n-1$ ja $n$. Laatan jakautunut kuorma muodostuu sen ylä- ja alapintaan kohdistuvista paineista seuraavasti

$$
\begin{aligned}
\mathrm{q}_{n}(x, y, t) & =\mathrm{p}_{n-1}\left(x, y, z_{n-}, t\right)-\mathrm{p}_{n}\left(x, y, z_{n+}, t\right) \\
& =\left(\hat{\mathrm{p}}_{n-1+} e^{-\mathrm{j} k_{z n-1} z_{n-}}+\hat{\mathrm{p}}_{n-1-1} e^{\mathrm{j} k_{z n-1} z_{n-}}-\hat{\mathrm{p}}_{n+} e^{-\mathrm{j} k_{z n} z_{n+}}\right) e^{\mathrm{j}\left(\omega t-k_{x} x-k_{y} y\right)}
\end{aligned}
$$

Soveltamalla kaavoja (43) ja (36) saadaan tästä

$$
\mathrm{q}_{n}(x, y, t)=\hat{\mathrm{q}}_{n} e^{\mathrm{j}\left(\omega t-k_{x} x-k_{y} y\right)}
$$

missä kuorma-amplitudi on

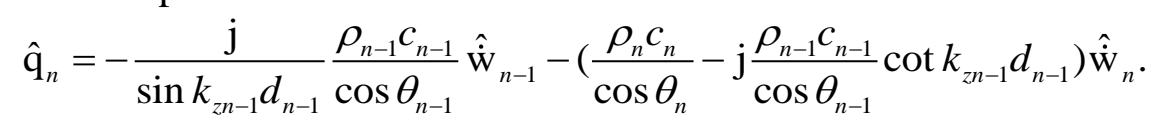

\section{Yhtälöryhmä kompleksisille taipuma-amplitudeille}

Sijoittamalla kuorma-amplitudit (134), (137) ja (140) yhtälöihin (131) saadaan yhtälöryhmä

$$
\mathbf{Z} \hat{\mathbf{w}}=2 \hat{\mathbf{p}}_{I}
$$

missä

$$
\hat{\dot{\mathbf{w}}}=\left\{\begin{array}{c}
\hat{\dot{\mathrm{w}}}_{1} \\
\vdots \\
\hat{\dot{\mathrm{W}}}_{n}
\end{array}\right\}
$$

on kompleksisten taipumanopeusamplitudien muodostama pystyvektori ja $\hat{\mathbf{p}}_{I}$ on vakio vektori, jonka ensimmäinen alkio on tuloaallon kompleksinen paineamplitudi $\hat{\mathrm{p}}_{I}$ ja muut alkiot ovat nollia. Matriisia $\mathbf{Z}$ kutsutaan tässä systeemin impedanssimatriisiksi ja sen nollasta eroavat alkiot ovat 


$$
\begin{aligned}
& \mathrm{Z}_{11}=\mathrm{Z}_{1}^{*}+\frac{\rho_{0} c_{0}}{\cos \theta_{0}}-\mathrm{j} \frac{\rho_{1} c_{1}}{\cos \theta_{1}} \cot k_{z 1} d_{1}, \\
& \mathrm{Z}_{12}=\mathrm{j} \frac{\rho_{1} c_{1}}{\cos \theta_{1}} \frac{1}{\sin k_{z 1} d_{1}}, \\
& \mathrm{Z}_{i, i-1}=\mathrm{j} \frac{\rho_{i-1} c_{i-1}}{\cos \theta_{i-1}} \frac{1}{\sin k_{z i-1} d_{i-1}}, \\
& \left.\mathrm{Z}_{i, i}=\mathrm{Z}_{i}^{*}-\mathrm{j} \frac{\rho_{i-1} c_{i-1}}{\cos \theta_{i-1}} \cot k_{z i-1} d_{i-1}-\mathrm{j} \frac{\rho_{i} c_{i}}{\cos \theta_{i}} \cot k_{z i} d_{i},\right\} \quad i=2, \cdots, n-1 . \\
& \mathrm{Z}_{i, i+1}=\mathrm{j} \frac{\rho_{i} c_{i}}{\cos \theta_{i}} \frac{1}{\sin k_{z i} d_{i}}, \\
& \mathrm{Z}_{n, n-1}=\mathrm{j} \frac{\rho_{n-1} c_{n-1}}{\cos \theta_{n-1}} \frac{1}{\sin k_{z n-1} d_{n-1}}, \\
& \mathrm{Z}_{n, n}=\mathrm{Z}_{n}^{*}+\frac{\rho_{n} c_{n}}{\cos \theta_{n}}-\mathrm{j} \frac{\rho_{n-1} c_{n-1}}{\cos \theta_{n-1}} \cot k_{z n-1} d_{n-1},
\end{aligned}
$$

Jatkossa tarvitsemme pelkästään alimman laatan $n$ taipumanopeuden kompleksista amplitudia $\hat{\mathrm{W}}_{n}$ soveltamalla Cramerin sääntöä [6] yhtälöryhmään (141) saadaan sille tulos

$$
\hat{\dot{\mathrm{w}}}_{n}=2 \frac{\operatorname{det} \mathbf{Z}}{\operatorname{det} \mathbf{Z}} \hat{\mathrm{p}}_{I},
$$

missä det $\mathbf{Z}_{n}$ on sen matriisin $\mathbf{Z}_{n}$ determinantti, joka saadaan matriisista $\mathbf{Z}$, kun sen viimeisen sarakkeen ensimmäinen termi korvataan ykkösellä ja muut termit nollilla.

\section{Läpäisseen aallon kompleksisen paineamplitudin määrittäminen}

Läpäisseen aallon paineamplitudille $\hat{\mathrm{p}}_{T}=\hat{\mathrm{p}}_{+}$saadaan kaavan (36) perusteella

$$
\hat{\mathrm{p}}_{T}=e^{\mathrm{j} k_{z} z_{n+}} \frac{\rho_{n} c_{n}}{\cos \theta_{n}} \hat{\mathrm{w}}_{n}
$$

Sijoittamalla siihen lauseke (144) saadaan läpäisseen aallon paineen amplitudille tulos

$$
\hat{\mathrm{p}}_{T}=e^{\mathrm{j} k_{z} z_{n+}} \frac{2 \rho_{n} c_{n}}{\cos \theta_{n}} \frac{\operatorname{det} \mathbf{Z}}{\operatorname{det} \mathbf{Z}} \hat{\mathrm{p}}_{I} .
$$

Rajoitutaan tässä tyypilliseen tapaukseen, jossa rakenteen molemmilla puolilla on ilmaa, jolloin $\rho_{n}=\rho, c_{n}=c, \theta_{n}=\theta$. Rakenteen äänenläpäisevyyskerroin $\tau_{\angle}$ saadaan nyt kaavalla (58) ja ääneneristävyys $R_{\llcorner}$kaavalla (59).

\section{Kaksoisseinämän ääneneristävyys}

Kahdesta identtisesti laatasta ja niiden välisestä ilmaraosta koostuva kaksoisseinämä on tärkeä käytännön sovellus. Liitteessä B on johdettu soveltamalla kaavoja (143) ja (146) sen läpäisseen aallon kompleksiselle paineamplitudille lauseke 


$$
\hat{\mathrm{p}}_{T}=\frac{e^{2 \mathrm{j} k_{z} h}}{1+\frac{\mathrm{Z}^{*} \cos \theta}{\rho c}+\left(\frac{\mathrm{Z}^{*} \cos \theta}{2 \rho c}\right)^{2}\left(1-e^{-2 \mathrm{j} k_{z} d}\right)} \hat{\mathrm{p}}_{I},
$$

missä $d$ on laattojen välisen ilmatilan paksuus ja $h$ on laatan paksuus. Tämä tulos on alun perin esitetty lähteessä [9] sillä erolla, että oikean puolen termi $e^{2 \mathrm{j} k_{z} h}$ puuttuu. Ero johtuu siitä, että kyseisessä artikkelissa laattojen paksuudet on otaksuttu ilmatilan paksuuteen nähden häviävän pieneksi $(h / d<<1)$, kun taas tässä artikkelissa näin ei ole menetelty. Liitteessä B on myös johdettu kaksoisseinämän ääneneristävyydelle kaava lauseke

$$
R_{L}=10 \lg \left|1+\frac{\mathrm{Z}^{*} \cos \theta}{\rho c}+\left(\frac{\mathrm{Z}^{*} \cos \theta}{2 \rho c}\right)^{2}\left(1-e^{-2 \mathrm{j} k_{z} d}\right)\right|^{2} .
$$

Laatan aaltoimpedanssi on yleisessä tapauksessa kompleksinen ja voidaan esittää muodossa $\mathrm{Z}^{*}=X^{*}+\mathrm{j} Y^{*}$. Vaimentamattomassa tapauksessa $(\eta=0)$ se on imaginaarinen ja muotoa $\mathrm{Z}^{*}=\mathrm{j} Y^{*}$, missä $Y^{*}$ on reaalinen. (Tämä voidaan todeta Kirchhoff-laatan tapauksessa kaavojen (80) ja (77) sekä Reissner-Mindlin-laatan tapauksessa kaavojen (89) ja (86) perusteella.) Liitteessä B on vielä johdettu reaalimuotoinen kaava

$$
R_{L}=10 \lg \left[1+\left(\frac{Y^{*} \cos \theta}{\rho c}\right)^{2}\left(\cos k_{z} d-\frac{Y^{*}}{2 \rho c} \cos \theta \sin k_{z} d\right)^{2}\right],
$$

jolla kaksoisseinämän ääneneristävyys voidaan laskea vaimentamattomassa tapauksessa. Tämä tulos on esitetty lähteessä [4]. Todetaan, että tässä artikkelissa käytetty laattojen paksuuksien täsmällisempi käsittely ei kuitenkaan paranna ääneneristävyydelle saatavia tuloksia.

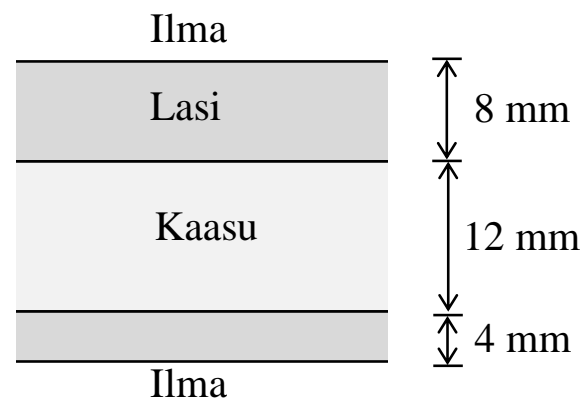

Kuva 14. Kahdesta lasista ja niiden välisestä kaasusta muodostuva ikkuna

\section{Kahdesta lasista ja niiden välisestä kaasusta muodostuva ikkuna}

Tarkastellaan esimerkkinä kuvan 14 kahdesta lasista ja niiden välisestä kaasusta muodostuvaa ikkunaa. Verrataan ikkunan ääneneristävyyttä, kun välikaasuna on ilma tai raskas $\mathrm{SF}_{6}$-kaasu. Ilman tiheys ja äänen nopeus ilmassa ovat $\rho_{0}=1,21 \mathrm{~kg} / \mathrm{m}^{3}$ ja $c_{0}=343 \mathrm{~m} / \mathrm{s}$ sekä $\mathrm{SF}_{6}$-kaasun vastaavat suureet $\rho_{1}=6,12 \mathrm{~kg} / \mathrm{m}^{3}$ ja $c_{1}=133 \mathrm{~m} / \mathrm{s}$. Lasin kimmomoduuli, Poissonin luku, häviökerroin ja tiheys ovat $E=6,76 \cdot 10^{10} \mathrm{~N} / \mathrm{m}^{2}, \quad v=0,33$, $\eta=1 \cdot 10^{-2}$ ja $\rho=2400 \mathrm{~kg} / \mathrm{m}^{3}$. Kuvassa 15 on esitetty ikkunan ääneneristävyys $R$ taajuuden $f$ funktiona, kun välikaasuna on ilma ja $\mathrm{SF}_{6}$-kaasu. Kuvissa 16 ja 17 on esitetty 
ikkunan laskennallinen ääneneristävyyskäyrä, vertailukäyrä ja niiden avulla määritetty ääneneristysluku $R_{w}$, kun välikaasuna on ilma ja $\mathrm{SF}_{6}$-kaasu. Ääneneristysluvuiksi saatiin ilman ja kaasun tapauksissa $R_{w}=24 \mathrm{~dB}$ ja $R_{w}=31 \mathrm{~dB}$.

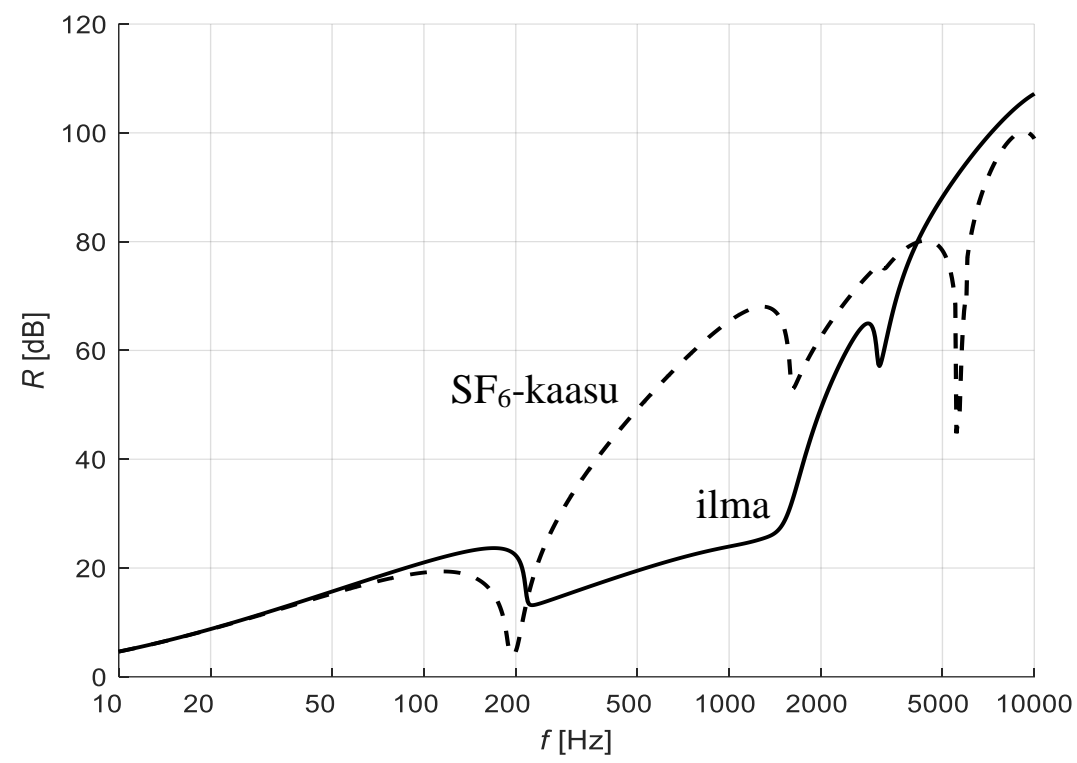

Kuva 15. Ikkunan ääneneristävyys $R$ taajuuden $f$ funktiona

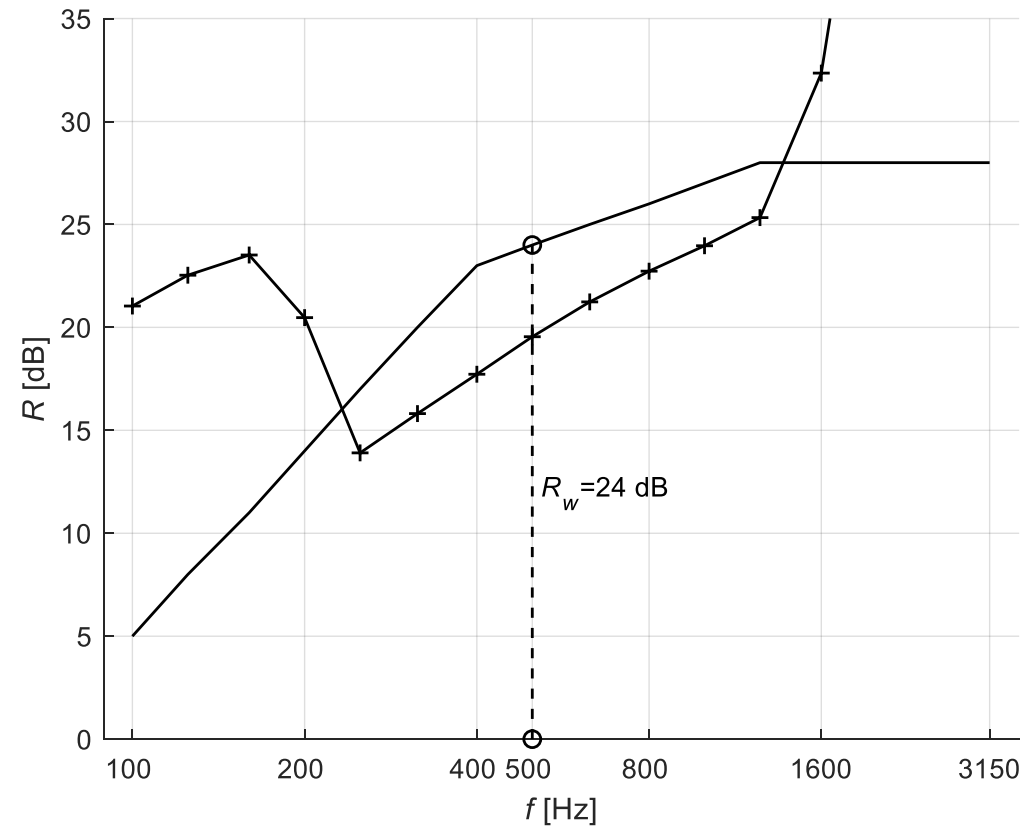

Kuva 16. Ikkunan laskennallinen ääneneristävyyskäyrä + , vertailukäyrä - ja niiden avulla määritetty ääneneristysluku $R_{w}$, kun lasien välissä on ilmaa. 


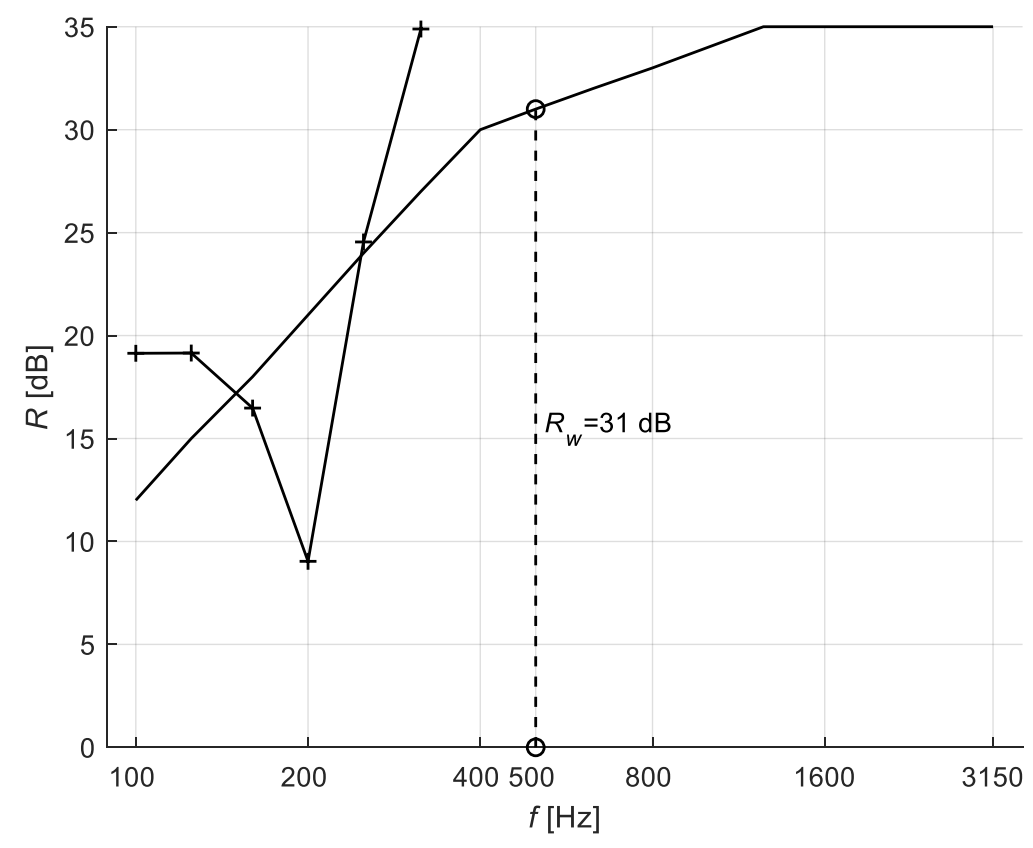

Kuva 17. Ikkunan laskennallinen ääneneristävyyskäyrä + , vertailukäyrä - ja niiden avulla määritetty ääneneristysluku $R_{w}$, kun lasien välissä on raskasta $\mathrm{SF}_{6}$ kaasua

\section{Johtopäätökset}

Artikkelissa käsiteltiin rakenteiden ilmaäänen eristävyyden laskennalliseen määrittämiseen liittyviä kysymyksiä ja laskennan eri vaiheita. Erityisesti tarkasteltiin laattoja ja niistä koostuvia kerroksellisia tasorakenteita. Ääniaaltojen rakenteen molemmin puolin sekä mahdollisissa laattojen välisissä raoissa oletettiin olevan tasoaaltoja. Laattojen otaksuttiin olevan $(x, y)$-tason suuntaisia ja ulottuvan tasossaan äärettömän kauas. Näiden otaksumien vallitessa rakenteen ääneneristävyydelle vinosti kohtaavalle ääniaallolle on olemassa analyyttisiä ratkaisuja, joista muutamia tässä artikkelissa pyrittiin johtamaan mahdollisimman selkeästi ja johdonmukaisesti. Tällaiset ratkaisut mahdollistavat rakenteen ääneneristävyyden määrittämisen diffuusille kentälle ja koko ääneneristävyystehtävän ratkaisemisen kohtuullisessa ajassa. Rajoitustensa vuoksi laskentamalli ei kuitenkaan huomioi rakenteen tukia eikä sen liittymistä muihin rakenteisiin. Tämän vuoksi sillä saadut tulokset eivät välttämättä kovin hyvin vastaa laboratoriossa tai kenttäolosuhteissa saatuja koetuloksia. Ne voivan kuitenkin olla suuntaa-antavia esimerkiksi verrattaessa erilaisten rakenteiden ilmanääneneristävyyttä toisiinsa. 


\section{Viitteet}

[1] L.L. Beranek, I.L. Ver, Noise and Vibration Control Engineering, Principles and Applications. John Wiley \& Sons. Inc., 1992.

[2] L. Cremer, M. Heckl, B.A.T. Petersson, Structure-Borne Sound, Structural Vibrations and Sound Radiation at Audio Frequencies. $3^{\text {rd }}$ Edition, SpringerVerlag, 2005.

[3] D.G. Reynolds, Engineering Principles of Acoustics, Noise and Vibration control, Allyn and Bacon, Inc., 1981.

[4] L.L. Beranek, Sound reduction, McGraw-Hill, 1960, pp. 290-298.

[5] Ääneneristys ohjeet, C5, Ympäristöministeriö 1985.

[6] E. Kreyszig, Advanced Engineering Mathematics, $7^{\text {th }}$ Edition, John Wiley \& Sons Inc., 1993.

[7] S.P. Timoshenko, S. Woinowsky-Krieges, Theory of Plates and Shells. McGrawHill Book Company, Inc., 1959.

[8] R.D. Mindlin, Influence of Rotary Inertia and Shear on Flexural Motion of Elastic Plates, Journal of Applied Mechanics 18 (1951) 31-38.

[9] A. London, Transmission of reverberant sound through double walls, Journal of Research of the National Bureau of Standards, 44 (1950) RP1998.

http://dx.doi.org/10.6028/jres.044.006

Jukka Aalto

Aalto-yliopisto, Insinööritieteiden korkeakoulu, Rakennustekniikan laitos PL 12100, 00076 Aalto

jukka.aalto@aalto.fi 
Liite A: Isotrooppisen Reissner-Mindlin-laatan taipuman differentiaaliyhtälön johto

\section{A.1 Laatan liikeyhtälöt rotaatiohitaus huomioiden}

Koska rakenteiden mekaniikan oppikirjoissa ei tavallisesti esitetä laatan liikeyhtälöitä rotaatiohitaus huomioiden, johdetaan ne tässä. Differentiaaliseen laatan osaan vaikuttava $z$-akselin suuntainen voimaresultantti on kuvan A.1 (a) perusteella

$$
\begin{aligned}
d F_{z} & =\left(-Q_{x}+Q_{x}+\frac{\partial Q_{x}}{\partial x} d x\right) d y+\left(-Q_{y}+Q_{y}+\frac{\partial Q_{y}}{\partial y} d y\right) d x+q d x d y \\
& =\left(\frac{\partial Q_{x}}{\partial x}+\frac{\partial Q_{y}}{\partial y}+q\right) d x d y,
\end{aligned}
$$

missä $Q_{x}$ ja $Q_{y}$ ovat laatan leikkausvoimat ja $q$ on jakautunut kuorma.

(a)

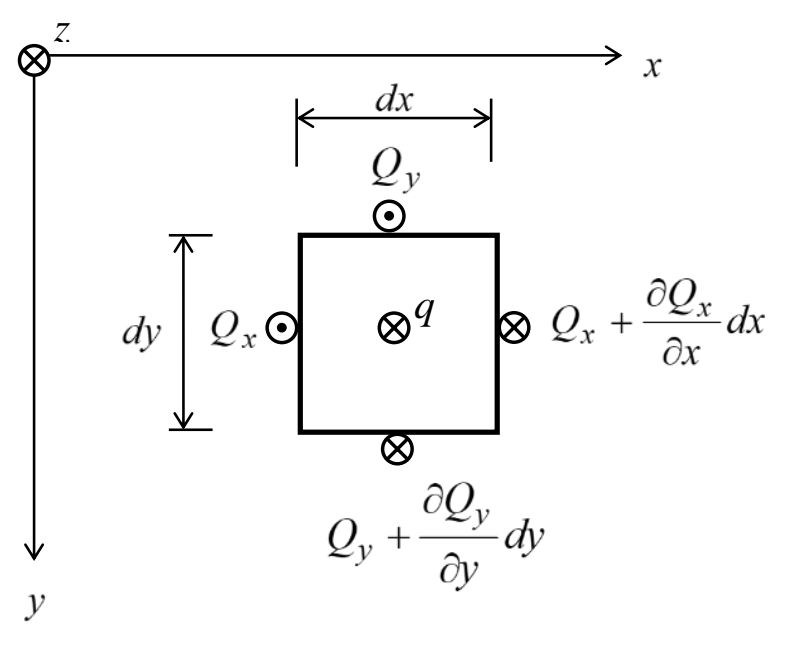

(c)

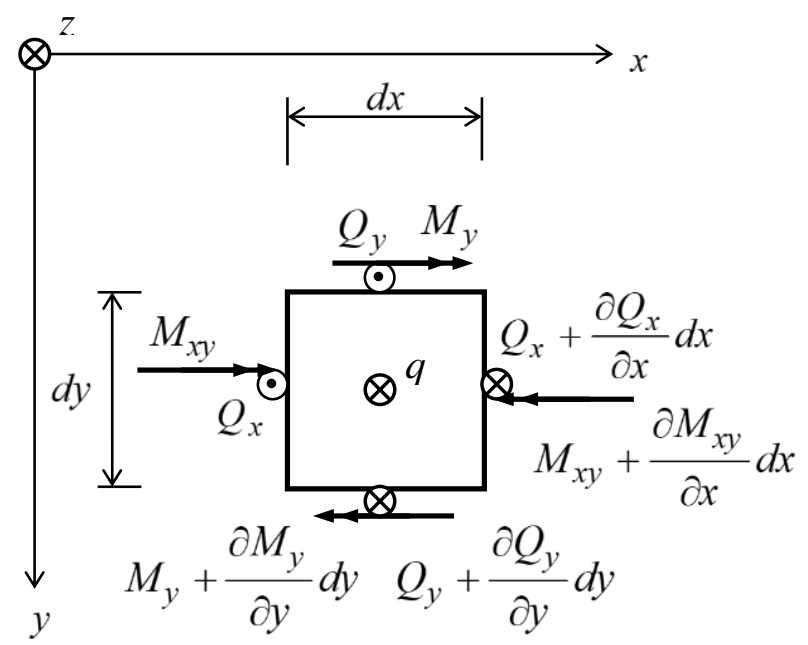

(b)

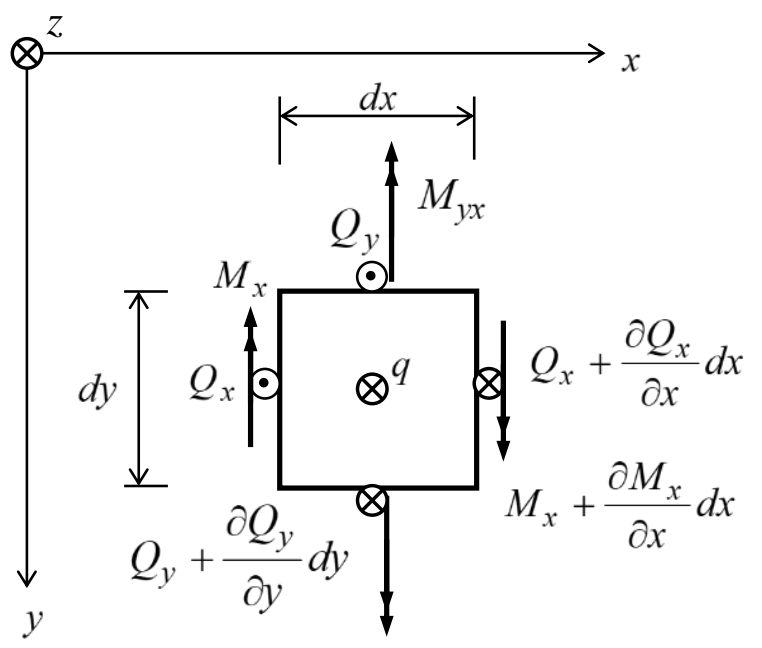

Kuva A.1 Differentiaaliseen laatan osaan vaikuttavia voimia ja momentteja liikeyhtälöiden johtamista varten 
Differentiaaliseen laatan osaan vaikuttava momenttiresultantti sen keskipisteen kautta kulkevan $y$-akselin suuntaisen akselin suhteen on kuvan A.1 (b) perusteella

$$
\begin{aligned}
d M_{y}= & -Q_{x} d y \frac{d x}{2}-\left(Q_{x}+\frac{\partial Q_{x}}{\partial x} d x\right) d y \frac{d x}{2} \\
& +\left(-M_{x}+M_{x}+\frac{\partial M_{x}}{\partial x} d x\right) d y+\left(-M_{y x}+M_{y x}+\frac{\partial M_{y x}}{\partial y} d y\right) d x \\
= & \left(-Q_{x}+\frac{\partial M_{x}}{\partial x}+\frac{\partial M_{y x}}{\partial y}\right) d x d y-\frac{1}{2} \frac{\partial Q_{x}}{\partial x} d x^{2} d y \\
\approx & \left(-Q_{x}+\frac{\partial M_{x}}{\partial x}+\frac{\partial M_{y x}}{\partial y}\right) d x d y .
\end{aligned}
$$

Differentiaaliseen laatan osaan vaikuttava momenttiresultantille sen keskipisteen kautta kulkevan $x$-akselin suuntaisen akselin suhteen saadaan kuvan A.1 (c) perusteella vastaavasti

$$
d M_{x}=\left(Q_{y}-\frac{\partial M_{x y}}{\partial x}-\frac{\partial M_{y}}{\partial y}\right) d x d y .
$$

Lausekkeissa (A2) ja (A3) $M_{x}$ ja $M_{y}$ ovat laatan taivutusmomentit ja $M_{x y}=M_{y x}$ on vääntömomentti. Momenttiresultanttien $d M_{x}$ ja $d M_{y}$ positiiviset suunnat on valittu tässä oikean käden ruuvisäännön mukaisesti. Jäykäksi kappaleeksi otaksutun differentiaalisen laatan osan vastaavia rotaatiokomponentteja merkitään tässä $\theta_{x}$ ja $\theta_{y}$. Sen liikeyhtälöt ovat

$$
d F_{z}=m d x d y \frac{\partial^{2} w}{\partial t^{2}}, \quad d M_{x}=J d x d y \frac{\partial^{2} \theta_{x}}{\partial t^{2}}, \quad d M_{y}=J d x d y \frac{\partial^{2} \theta_{y}}{\partial t^{2}} .
$$

missä $m$ on laatan massa ja $J$ sen rotaatiohitaus pintayksikköä kohti ja $w$ on taipuma. Rotaatiokomponenteilla $\theta_{x}, \theta_{y}$ ja laatan normaalin kiertymillä $\varphi_{x}, \varphi_{y}$ on yhteydet

$$
\theta_{x}=\varphi_{y}, \quad \theta_{y}=-\varphi_{x} .
$$

Niitä käyttäen laatan osan liikeyhtälöt (A.4) saavat muodon

$$
d F_{z}=m d x d y \frac{\partial^{2} w}{\partial t^{2}}, \quad d M_{y}=-J d x d y \frac{\partial^{2} \varphi_{x}}{\partial t^{2}}, \quad d M_{x}=J d x d y \frac{\partial^{2} \varphi_{y}}{\partial t^{2}} .
$$

Sijoittamalla näihin lausekkeet (A.1), (A.2) ja (A.3) ja jakamalla puolittain tulolla $d x d y$ saadaan laatan liikeyhtälöiksi

$$
\begin{aligned}
& \frac{\partial Q_{x}}{\partial x}+\frac{\partial Q_{y}}{\partial y}=-q+m \frac{d^{2} w}{d t^{2}}, \\
& Q_{x}=\frac{\partial M_{x}}{\partial x}+\frac{\partial M_{y x}}{\partial y}+J \frac{d^{2} \varphi_{y}}{d t^{2}}, \\
& Q_{y}=\frac{\partial M_{x y}}{\partial x}+\frac{\partial M_{y}}{\partial y}+J \frac{d^{2} \varphi_{x}}{d t^{2}} .
\end{aligned}
$$

Tavanomaiset liikeyhtälöt, joissa rotaatiohitautta ei huomioida, saadaan näistä asettamalla $J=0$. 


\section{A.2 Isotrooppisen Reissner-Mindlin-laatan taipuman differentiaaliyhtälö}

Johdetaan isotrooppiselle Reissner-Mindlin-laatalle osittaisdifferentiaaliyhtälö, jossa tuntemattomana on pelkästään taipuma. Laatan muut yhtälöt liikeyhtälöiden (A.7) lisäksi oletetaan tässä yleisesti tunnetuiksi ja annetaan ilman johtoa. Normaalin kiertymien, taipuman ja liukumakulmien yhteydet ovat

$$
\varphi_{x}=\frac{\partial w}{\partial x}-\gamma_{x}, \quad \varphi_{y}=\frac{\partial w}{\partial y}-\gamma_{y},
$$

missä $\gamma_{x}$ ja $\gamma_{y}$ ovat liukumakulmat. Momenttien ja normaalinkiertymien yhteydet ovat

$$
M_{x}=-B\left(\frac{\partial \varphi_{x}}{\partial x}+v \frac{\partial \varphi_{y}}{\partial y}\right), \quad M_{y}=-B\left(\frac{\partial \varphi_{y}}{\partial y}+v \frac{\partial \varphi_{x}}{\partial x}\right), \quad M_{x y}=-B \frac{1-v}{2}\left(\frac{\partial \varphi_{x}}{\partial y}+\frac{\partial \varphi_{y}}{\partial x}\right),
$$

missä $B$ on laatan taivutusjäykkyys. Leikkausvoimien ja liukumakulmien yhteydet ovat

$$
Q_{x}=S \gamma_{x}, \quad Q_{y}=S \gamma_{y},
$$

missä $S$ on laatan leikkausjäykkyys. Johdetaan taipuman differentiaaliyhtälö lähtien näistä yhtälöistä. Yhtälöistä (A.7) ja (A.9) seuraa

$$
\left(B \nabla^{2}-J \frac{\partial^{2}}{\partial t^{2}}\right)\left(\frac{\partial \varphi_{x}}{\partial x}+\frac{\partial \varphi_{y}}{\partial y}\right)=q-m \frac{\partial^{2} w}{\partial t^{2}},
$$

missä

$$
\nabla^{2}=\frac{\partial}{\partial x^{2}}+\frac{\partial}{\partial y^{2}}
$$

Sijoittamalla tähän normaalin kiertymien lausekkeet (A.8) ja ottamalla huomioon yhteydet (A.10) saadaan

$$
\left(B \nabla^{2}-J \frac{\partial^{2}}{\partial t^{2}}\right)\left(\frac{\partial^{2} w}{\partial x^{2}}+\frac{\partial^{2} w}{\partial y^{2}}\right)-\left(B \nabla^{2}-J \frac{\partial^{2}}{\partial t^{2}}\right) \frac{1}{S}\left(\frac{\partial Q_{x}}{\partial x}+\frac{\partial Q_{y}}{\partial y}\right)=q-m \frac{\partial^{2} w}{\partial t^{2}}
$$

ja ottamalla vielä huomioon yhteys (A.7a) ensin

$$
\left(B \nabla^{2}-J \frac{\partial^{2}}{\partial t^{2}}\right) \nabla^{2} w-\left(B \nabla^{2}-J \frac{\partial^{2}}{\partial t^{2}}\right) \frac{1}{S}\left(-q+m \frac{\partial^{2} w}{\partial t^{2}}\right)=q-m \frac{\partial^{2} w}{\partial t^{2}},
$$

sitten

$$
\left(\nabla^{2}-\frac{m}{S} \frac{\partial^{2}}{\partial t^{2}}\right)\left(B \nabla^{2}-J \frac{\partial^{2}}{\partial t^{2}}\right) w+m \frac{\partial^{2} w}{\partial t^{2}}=\left(1-\frac{B}{S} \nabla^{2}+\frac{J}{S} \frac{\partial^{2}}{\partial t^{2}}\right) q
$$

ja lopuksi

$$
B \nabla^{4} w-\left(J+\frac{m B}{S}\right) \nabla^{2} \frac{\partial^{2} w}{\partial t^{2}}+\frac{m J}{S} \frac{\partial^{4} w}{\partial t^{4}}+m \frac{\partial^{2} w}{\partial t^{2}}=q-\frac{B}{S} \nabla^{2} q+\frac{J}{S} \frac{\partial^{2} q}{\partial t^{2}} .
$$

Tätä yhtälöä kutsutaan tässä artikkelissa isotrooppisen Reissner-Mindlin-laatan taipuman differentiaaliyhtälöksi. Se on esitetty homogeeniselle laatalle lähteessä [8]. Kirjoittajan käsityksen mukaan vastaavaa yhtälöä, jossa tuntemattomana on pelkkä taipuma, ei voida johtaa ortotrooppiselle Reissner-Mindlin-laatalle. 
Liite B: Kaksoisseinämän ääneneristävyyden kaavojen johto

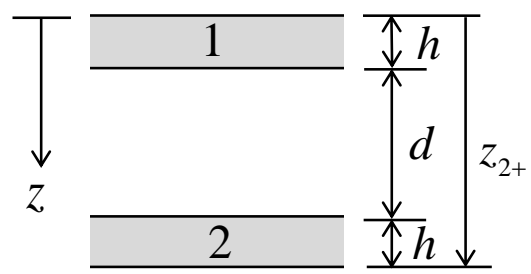

Kuva B.1 Kaksoisseinämä

Tarkastellaan kuvan B.1 kahdesta identtisesti laatasta ja niiden välisestä ilmaraosta koostuvaa kaksoisseinämää. Kaavan (143) perusteella impedanssimatriisin alkioille saadaan

$$
\begin{aligned}
\mathrm{Z}_{11} & =\mathrm{Z}_{22}=\mathrm{Z}^{*}+\frac{\rho c}{\cos \theta}\left(1-\mathrm{j} \cot k_{z} d\right)=\mathrm{Z}^{*}+\frac{\rho c}{\cos \theta} \frac{\sin k_{z} d-\mathrm{j} \cos k_{z} d}{\sin k_{z} d} \\
& =\mathrm{Z}^{*}-\mathrm{j} \frac{\rho c}{\cos \theta} \frac{\cos k_{z} d+\mathrm{j} \sin k_{z} d}{\sin k_{z} d}=\mathrm{Z}^{*}+\frac{2 \rho c}{\cos \theta} \frac{e^{\mathrm{j} k_{z} d}}{e^{\mathrm{j} k_{z} d}-e^{-\mathrm{j} k_{z} d}} \\
& =\mathrm{Z}^{*}+\frac{2 \rho c}{\cos \theta} \frac{1}{1-e^{-2 \mathrm{j} k_{z} d}}=\frac{2 \rho c}{\cos \theta}\left(\gamma+\frac{1}{1-e^{-2 \mathrm{j} k_{z} d}}\right), \\
\mathrm{Z}_{12} & =\mathrm{Z}_{21}=\mathrm{j} \frac{\rho c}{\cos \theta} \frac{1}{\sin k_{z} d}=-\frac{2 \rho c}{\cos \theta} \frac{1}{e^{\mathrm{j} k_{z} d}-e^{-\mathrm{j} k_{z} d}}=-\frac{2 \rho c}{\cos \theta} \frac{e^{-\mathrm{j} k_{z} d}}{1-e^{-2 \mathrm{j} k_{z} d}} .
\end{aligned}
$$

missä otettiin käyttöön väliaikainen lyhennysmerkintä

$$
\gamma=\frac{\mathrm{Z}^{*} \cos \theta}{2 \rho c}
$$

Läpäisseen aallon amplitudille $\hat{\mathrm{p}}_{T}$ saadaan kaavan (146) perusteella

$$
\hat{\mathrm{p}}_{T}=e^{\mathrm{j} k_{z} z_{2+}} \frac{2 \rho c}{\cos \theta} \frac{\operatorname{det} \mathbf{Z}_{2}}{\operatorname{det} \mathbf{Z}} \hat{\mathrm{p}}_{I}=e^{\mathrm{j} k_{z}(d+2 h)} \frac{2 \rho c}{\cos \theta} \frac{-\mathrm{Z}_{21}}{\mathrm{Z}_{11} \mathrm{Z}_{21}-\mathrm{Z}_{12} \mathrm{Z}_{21}} \hat{\mathrm{p}}_{I} .
$$

ja sijoittamalla tähän tulokset (B.1) edelleen

$$
\hat{\mathrm{p}}_{T}=e^{\mathrm{j} k_{z}(d+2 h)} \frac{\frac{e^{-\mathrm{j} k_{z} d}}{1-e^{-2 \mathrm{j} k_{z} d}}}{\left(\gamma+\frac{1}{1-e^{-2 \mathrm{j} k_{z} d}}\right)^{2}-\frac{e^{-2 \mathrm{j} k_{z} d}}{\left(1-e^{-2 \mathrm{j} k_{z} d}\right)^{2}}} \hat{\mathrm{p}}_{I}=\frac{e^{2 \mathrm{j} k_{z} h}}{1+2 \gamma+\gamma^{2}\left(1-e^{-2 \mathrm{j} k_{z} d}\right)} \hat{\mathrm{p}}_{I}
$$

ja huomioimalla yhteys (B.2) lopulta

$$
\hat{\mathrm{p}}_{T}=\frac{e^{2 \mathrm{j} k_{z} h}}{1+\frac{\mathrm{Z}^{*} \cos \theta}{\rho c}+\left(\frac{\mathrm{Z}^{*} \cos \theta}{2 \rho c}\right)^{2}\left(1-e^{-2 \mathrm{j} k_{z} d}\right)} \hat{\mathrm{p}}_{I} .
$$

Ääneneristävyyskertoimelle saadaan nyt

$$
\tau_{L} \equiv\left|\frac{\hat{\mathrm{p}}_{T}}{\hat{\mathrm{p}}_{I}}\right|^{2}=\frac{1}{\left|1+\frac{\mathrm{Z}^{*} \cos \theta}{\rho c}+\left(\frac{\mathrm{Z}^{*} \cos \theta}{2 \rho c}\right)^{2}\left(1-e^{-2 \mathrm{j} k_{z} d}\right)\right|^{2}}
$$


ja ääneneristävyydelle

$$
R_{L} \equiv 10 \lg \frac{1}{\tau_{L}}=10 \lg \left|1+\frac{\mathrm{Z}^{*} \cos \theta}{\rho c}+\left(\frac{\mathrm{Z}^{*} \cos \theta}{2 \rho c}\right)^{2}\left(1-e^{-2 \mathrm{j} k_{z} d}\right)\right|^{2} .
$$

Vaimentamattomassa tapauksessa $(\eta=0)$ aaltoimpedanssi on muotoa $\mathrm{Z}^{*}=\mathrm{j} Y^{*}$, missä $Y^{*}$ on reaalinen. Lauseke (B.7) saa tällöin aluksi muodon

$$
R_{\llcorner}=10 \lg \left|1+\mathrm{j} \frac{Y^{*} \cos \theta}{\rho c}-\left(\frac{Y^{*} \cos \theta}{2 \rho c}\right)^{2}\left(1-e^{-2 \mathrm{j} k_{z} d}\right)\right|^{2} .
$$

Käyttämällä väliaikaista lyhennysmerkintää

$$
\beta=\frac{Y^{*} \cos \theta}{2 \rho c}
$$

muokataan lauseketta (B.8) edelleen seuraavasti

$$
\begin{aligned}
R_{L} & =10 \lg \left|1+2 \mathrm{j} \beta-\beta^{2}\left(1-e^{-2 \mathrm{j} k_{z} d}\right)\right|^{2} \\
& =10 \lg \left|1+2 \mathrm{j} \beta-\beta^{2}\left(1-\cos 2 k_{z} d+\mathrm{j} \sin 2 k_{z} d\right)\right|^{2} \\
& =10 \lg \left|1+2 \mathrm{j} \beta-2 \beta^{2}\left(\sin ^{2} k_{z} d+\mathrm{j} \sin k_{z} d \cos k_{z} d\right)\right|^{2} \\
& =10 \lg \left|1-2 \beta^{2} \sin ^{2} k_{z} d+2 \mathrm{j}\left(\beta-\beta^{2} \sin k_{z} d \cos k_{z} d\right)\right|^{2} \\
& =10 \lg \left[\left(1-2 \beta^{2} \sin ^{2} k_{z} d\right)^{2}+4\left(\beta-\beta^{2} \sin k_{z} d \cos k_{z} d\right)^{2}\right] \\
& =10 \lg \left[1+4 \beta^{2}\left(\cos ^{2} k_{z} d-2 \beta \sin k_{z} d \cos k_{z} d+\beta^{2} \sin ^{2} k_{z} d\right)\right] \\
& =10 \lg \left[1+4 \beta^{2}\left(\cos k_{z} d-\beta \sin k_{z} d\right)^{2}\right] .
\end{aligned}
$$

Huomioimalla yhteys (B.9) saadaan kaksoisseinämän ääneneristävyydelle reaalimuotoinen kaava

$$
R_{\llcorner}=10 \lg \left[1+\left(\frac{Y^{*} \cos \theta}{\rho c}\right)^{2}\left(\cos k_{z} d-\frac{Y^{*} \cos \theta}{2 \rho c} \sin k_{z} d\right)^{2}\right] .
$$

